\title{
Preliminary Criticality Safety Evaluation for In Situ Grouting in the Subsurface Disposal Area
}

\author{
L. J. Slate
}

August 2000

Idaho National Engineering and Environmental Laboratory Bechtel BWXT Idaho, LLC 


\title{
Preliminary Criticality Safety Evaluation for In-Situ Grouting in the Subsurface Disposal Area
}

\author{
Lawrence J. Slate
}

August 2000

Idaho National Engineering and Environmental Laboratory Idaho Falls, Idaho 83415

Prepared for the

U.S. Department of Energy

Assistant Secretary for Environmental Management

Under DOE Idaho Operations Office

Contract DE-AC07-99ID13727 


\section{Abstract}

A preliminary criticality safety evaluation is presented for in situ grouting in the Subsurface Disposal Area (SDA) at the Idaho National Engineering Laboratory. The grouting materials evaluated are cement and paraffin.

The evaluation determines physical and administrative controls necessary to preclude criticality and identifies additional information required for a final criticality safety evaluation.

The evaluation shows that there are no criticality concerns with cementitious grout but a neutron poison such as boron would be required for the use of the paraffin matrix.

Key words: boron, cement, concrete, controls, criticality, fissile, grout, injection, in situ, keff, paraffin, plutonium, Rocky Flats, waste 


\section{List of Acronyms}

CERCLA Comprehensive Environmental Response, Compensation, and Liability Act

DOE

EDF

EPA

FS

IDHW

INEEL

$\mathrm{k}_{\text {eff }}$ Department of Energy

Engineering Design File

Environmental Protection Agency

feasibility study

Idaho Department of Health and Welfare

Idaho National Engineering \& Environmental Laboratory

effective multiplication

MCNP Monte Carlo N-Particle Transport Code

$\mathrm{ml}$

milliliter

OU

Operating Unit

PCSE Preliminary Criticality Safety Evaluation

$\mathrm{Pu}$ plutonium

RFP

Rocky Flats Plant

RI

SDA

remediation investigation

TRU

Subsurface Disposal Area

transuranic waste

WAG

waste area group 


\section{Table of Contents}



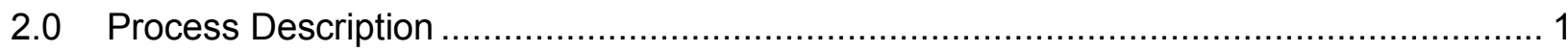

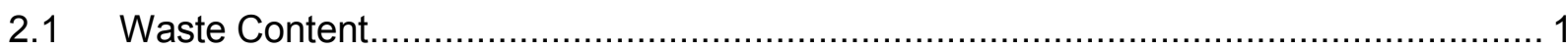

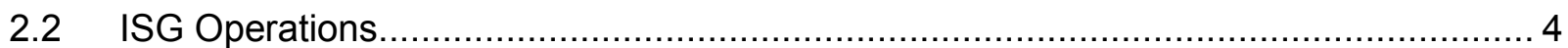

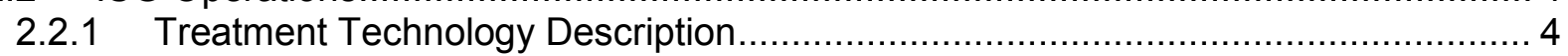

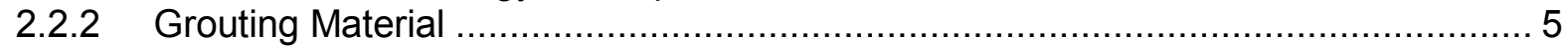

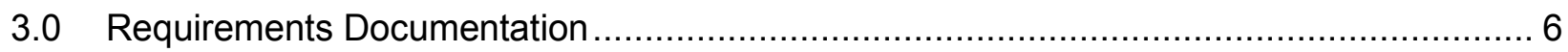



$4.1 \quad$ Description 0

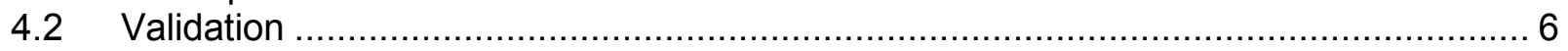

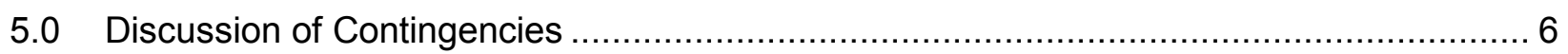



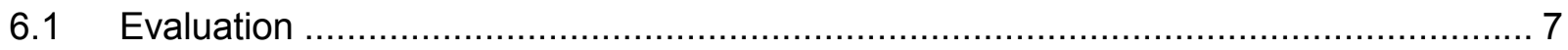

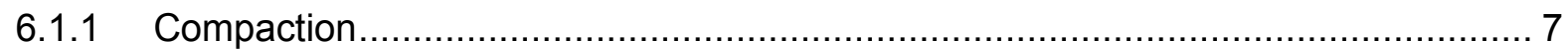

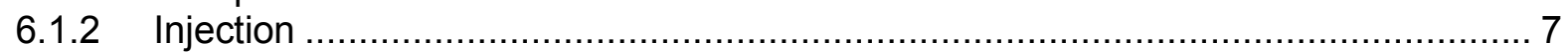





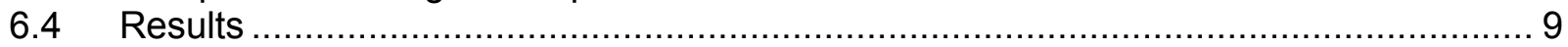

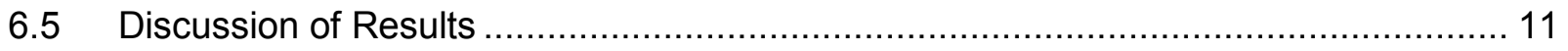

7.0 Design Features and Administratively Controlled Limits \& Requirements..................... 12

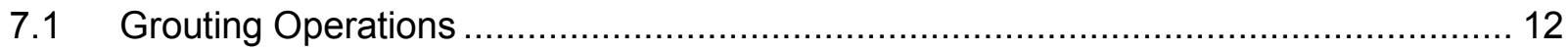



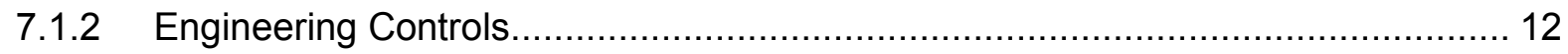

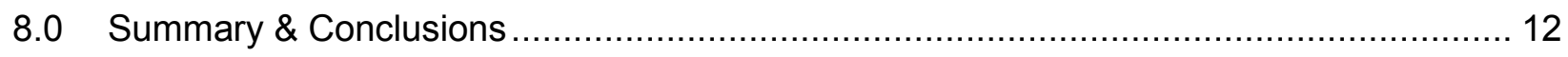

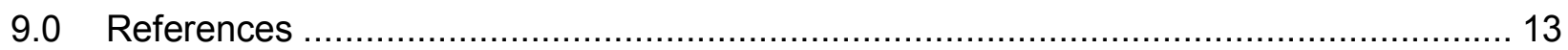




\section{List of Tables}

Table 1. Summary of Overloaded Drums Identified at the RWMC .................................... 3

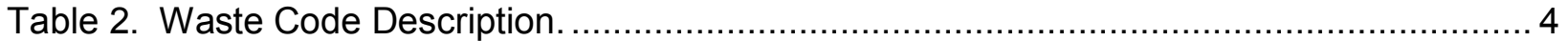

Table 3. Composition of Concrete Grout. ..................................................................... 8

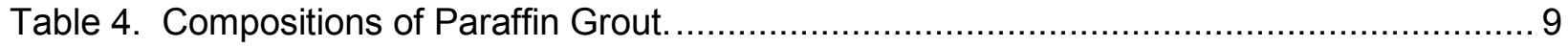

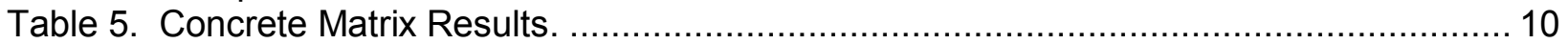

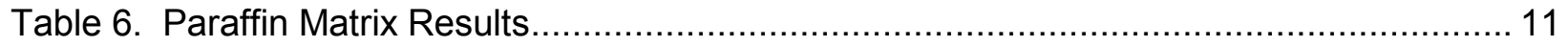



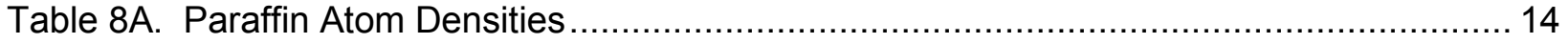

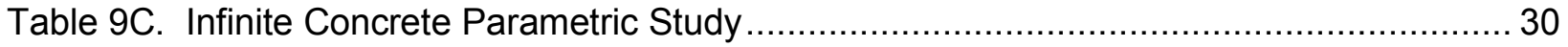

Table 10C. Finite (208 Liter) Concrete Parameter Study............................................ 31

Table 11C. Finite (104 Liter) Concrete Parametric Study............................................... 32

Table 12C. Infinite Paraffin Parametric Study........................................................... 33

Table 13C. Finite (208 Liter)Paraffin Parametric Study.................................................. 34

Table 14C. Finite (104 Liter) Paraffin Parametric Study.................................................. 35 


\section{List of Figures}

Figure 1. General Schematic of Grouting Operation. ............................................... 2

Figure 2. Top View of Thrust Block with Nominal Dimensions (Isometric) ............................ 5

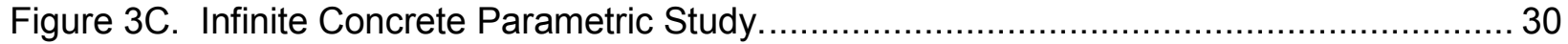

Figure 4C. Finite (208 Liter) Concrete Parametric Study. ............................................. 31

Figure 5C. Finite (104 Liter) Concrete Parametric Study. ........................................... 32

Figure 6C. Infinite Paraffin Parametric Study.......................................................... 33

Figure 7C. Finite (208 Liter)Paraffin Parametric Study. .............................................. 34

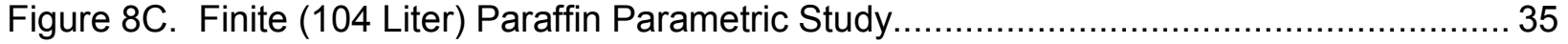




\subsection{Introduction}

This document presents the preliminary criticality safety evaluation (PCSE) for in situ grouting (ISG) in the Subsurface Disposal Area (SDA) at the Idaho National Engineering and Environmental Laboratory (INEEL). The SDA is located within the Radioactive Waste Management Complex (RWMC). The SDA was used to dispose of radioactive waste material in underground pits, trenches, soil vault rows, and similar structures. The majority of the waste buried in the SDA consists of by-products from the Department of Energy (DOE) Rocky Flats Plant (RFP) nuclear weapons program plutonium manufacturing process. The remaining waste is from INEEL onsite disposal and non-RFP offsite disposal.

The current contingency project plan is to perform ISG treatability studies to support the Waste Area Group (WAG) 7-13/14 remediation investigation (RI) and feasibility study (FS) process. The plan is developed by the DOE-Idaho Operations Office, the Environmental Protection Agency (EPA) Region 10, and the Idaho Department of Health and Welfare (IDHW).

The purpose of this document is to assess the proposed plans in conjunction with the method of operation to identify criticality controls related to ISG to ensure that a criticality hazard is not likely under credible scenarios. This document is issued in support of the Preliminary Safety Analysis Report (PSAR).

\subsection{Process Description}

The primary objective of this treatability study is to address the remaining questions relative to the use of in situ grouting to stabilize the variety of heterogeneous wastes and intermixed soils found in the SDA. Data will be gathered to provide information for evaluation of Comprehensive Environmental Response, Compensation, and Liability Act (CERCLA) criteria as part of the feasibility study for the WAG 7-13/14.

The stabilization concept includes injection of various cementitious, mineralogical, or polymeric stabilization agents into the void space created from the buried waste and contaminated soil matrix. Upon solidification, the resultant waste form encapsulates the buried waste material within a dense matrix, isolating the waste from surface and groundwater infiltration. Figure 1 illustrates a general view of the grouting operation. The reader is encouraged to become familiar with In-Situ Buried Waste Stabilization Technologies at the Idaho national Engineering and Environmental Laboratory (July 1998) for the details of the probing operation. The following sections describe the grouting operation in more detail and evaluate the criticality implications.

\subsection{Waste Content}

The precise content of the waste in the SDA is unknown. Several studies have been completed to estimate the contents of the waste disposed in the SDA (Thomas, and Clements). A more complete study is currently in progress to map the entire SDA and provide a graphical representation of the location of individual disposals and the contents of the shipments. Waste shipment log sheets have been discovered from the RFP that contain information such as the generator, amount of waste, and waste type. When the study is complete, generalizations can be made to determine the hazardous and radionuclide content of the waste. However, the exact fissile content of the waste will still be unknown. This is evident by the number of drums identified at the RWMC as overloaded. An Engineering Design File (EDF) by East (RWMCEDF-800) identifies 13 overloaded drums that have been discovered to date at the RWMC. An overloaded drum is defined as containing more than 380 grams $\mathrm{Pu}-239$ fissile gram equivalent 
(FGE). This mass limit is based on $75 \%$ of the minimum critical handbook value of 510 grams (Paxton, Pruvost, 1987) for an optimally moderated plutonium system. Table 1 summarizes the 13 overloaded drums and indicates the waste code of the suspect overloaded drums and the fissile mass.



Figure 1. General Schematic of Grouting Operation. 
Table 1. Summary of Overloaded Drums Identified at the RWMC

\begin{tabular}{||l|l|}
\hline Waste Code & $\begin{array}{l}\text { Maximum Measured Fissile Mass } \\
\text { Plus Uncertainty (grams) }\end{array}$ \\
\hline 393 & 992 \\
\hline 393 & 689 \\
\hline 393 & 974 \\
\hline 376 & 631 \\
\hline 376 & 427 \\
\hline 393 & 543 \\
\hline 376 & 1,138 \\
\hline 393 & 766 \\
\hline 409 & 396 \\
\hline 393 & 1,360 \\
\hline 393 & 536 \\
\hline 372 & 462 \\
\hline 409 & 544 \\
\hline
\end{tabular}

Table 1 indicates that one drum containing 1,360 grams of fissile mass has been identified to date at the RWMC. This mass can function as the bounding fissile mass starting point, but by no means is this the bounding fissile mass contained in the disposal area. A description of the content codes can be found in Table 2. Content code 409 was generated from September 1982 through January 1986, which corresponds to the time frame when the SDA was closed to underground disposal; therefore content code 409 is not disposed of in the SDA. 
Table 2. Waste Code Description.

\begin{tabular}{|c|c|c|}
\hline Waste Code & Content Description & Waste Description \\
\hline 372 & Grit & $\begin{array}{l}\text { Complete waste description is not available. } \\
\text { Available information indicates the waste } \\
\text { consists of "grit," such as aluminum oxide } \\
\text { and iron fines or pellets, used in grit blasting } \\
\text { operations. }\end{array}$ \\
\hline 376 & $\begin{array}{l}\text { Cemented Insulation and } \\
\text { Filter Media }\end{array}$ & $\begin{array}{l}\text { Pre-1979 wastes consist primarily of filter } \\
\text { media removed from various filters (pre- } \\
\text { filters, absolute filters, etc.). Since then, the } \\
\text { waste consists of filter media and whole } \\
\text { filters. Portland cement has been added to } \\
\text { all waste packages. The Portland cement is } \\
\text { added as a precautionary measure to } \\
\text { neutralize any residual nitric acid that may } \\
\text { be present in the waste and reduce the } \\
\text { potential for drum pressurization. }\end{array}$ \\
\hline 393 & $\begin{array}{l}\text { Sand, Slag, and Crucible } \\
\text { Heels }\end{array}$ & $\begin{array}{l}\text { Waste consists of the insoluble residue of } \\
\text { "heel" generated from processing } \\
\text { magnesium oxide sand, slag, and } \\
\text { magnesium oxide crucibles contaminated } \\
\text { with above discard amounts of plutonium. }\end{array}$ \\
\hline 409 & $\begin{array}{l}\text { Molten Salt 30\% } \\
\text { Unpulverized }\end{array}$ & $\begin{array}{l}\text { This waste consists of spent salt generated } \\
\text { by the molten salt extraction process used to } \\
\text { extract americium contamination from } \\
\text { plutonium metal. }\end{array}$ \\
\hline
\end{tabular}

\subsection{ISG Operations}

The basic premise of the ISG technology is to inject grout material into a selected subsurface area (waste pit) and produce a stable monolith. The monolith provides for both hot spot retrieval with enhanced contamination control, and/or encapsulation and stabilization of buried waste for in situ disposal. A series of beneficial bench-scale material studies and associated field-scale implementation tests have been performed. In 1997 the technology was successfully tested in the acid pit located within WAG 7 13/14. For a complete description of the acid pit treatment, the readers are encouraged to familiarize themselves with the Acid Pit Stabilization Project (INEEL/EXT-98-00009). A general description of the ISG operation is discussed in the following subsections.

\subsubsection{Treatment Technology Description}

The grouting apparatus consists of a modified well drilling system as illustrated in Figure 1 . The main components of the apparatus include a Casa Grande C-6 track mounted drilling/grouting rig or equivalent, drill stem, pump and hopper assembly, and thrust block. The drill stem is driven into the subsurface using rotopercussion powered by the Casa Grande C- 6 or equivalent. The drill stem has a diameter of nine centimeters and a nozzle attached to the end. While the drill stem is being driven into the subsurface, a small flow of grouting material is released from the nozzle to reduce the friction. The drill stem is driven through the targeted contaminated 
zone until the designated depth is reached (depth of waste). Once the drill stem has reached the designated depth, grouting material is injected at 400 bars $(5,800 \mathrm{psi})$ through the rotating drill stem into the waste zone. The drill stem is withdrawn in precise increments to allow the grouting material to fill all of the available void space within the waste. The nominal drill stem withdrawal time is one to two minutes. The process is repeated, using a nominal $50 \mathrm{~cm}$ triangle pitch as illustrated in Figure 2, until a series of interconnected columns form a solid monolith within the waste matrix. A thrust block is used to maintain the spacing of grouting holes and to control the release of grouting material to the surface. The trust block consists of a concrete block four feet wide, eight feet long, and eight to twelve inches thick. The trust block contains five inch diameter holes drilled through the thickness in a triangle pattern to establish the grid pattern and act as starter holes. The trust block is illustrated in Figure 2.

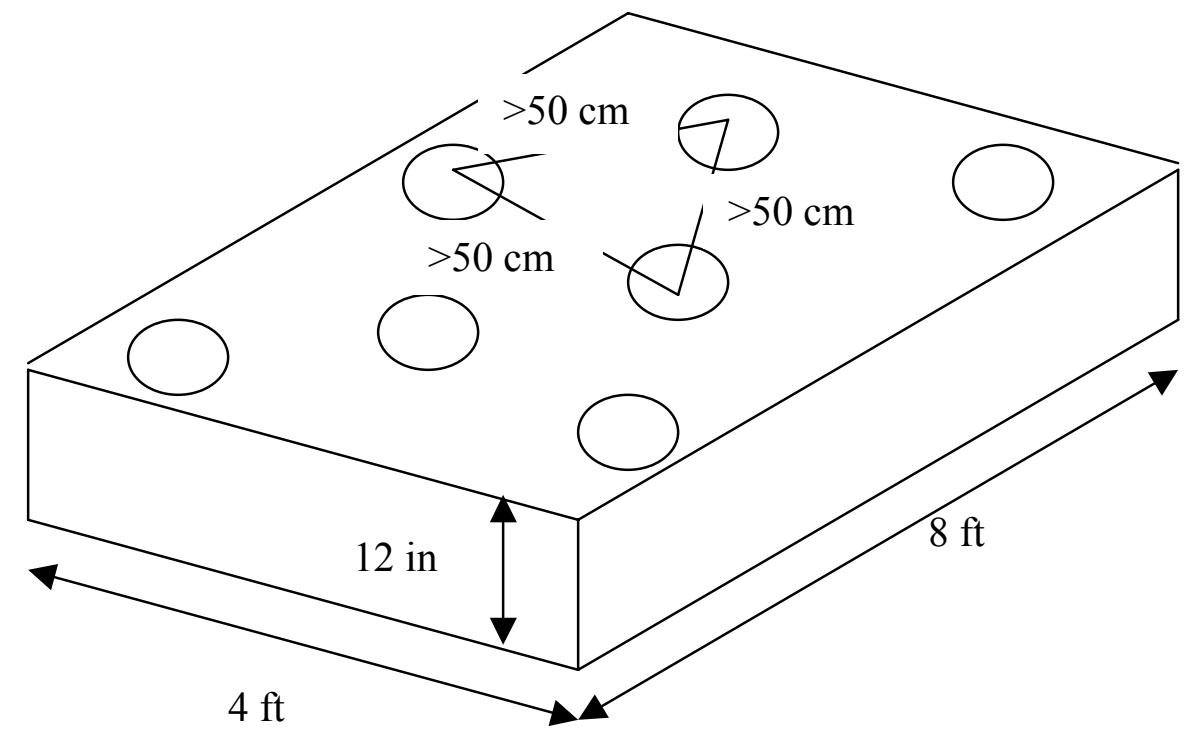

Figure 2. Top View of Thrust Block with Nominal Dimensions (Isometric)

\subsubsection{Grouting Material}

The two grouting materials proposed for this project include a Type-H (sulfate resistant) Portland cement grout and a paraffin grout. The cementitious grout is designed for block encapsulation of buried waste by the jet grouting process. The low viscosity grout (cement) is formulated to allow mixing and delivery in ordinary concrete trucks. The grout hardens on average of one day after injection when mixed with the soil. The paraffin grout is a low temperature natural paraffin wax based material originally developed for jet grouting leakage of hydrofluoric acid from surface impoundments. The additives within the molten paraffin allow the paraffin to blend with and even permeate soils regardless of their moisture content. The additives are multiple surfactants that also cause the grout to bond to water, oil, and buried debris. The paraffin grout is designed to fully encapsulate buried waste and to isolate the waste from water. Paraffin grouted areas will fill fractures and will minimize the potential of fugitive dust during excavation. 


\subsection{Requirements Documentation}

This section specifies unique DOE orders or guides, ANS standards, Code of Federal Regulations, or internal requirement documents which apply to this CSE. General requirement documents such as DOE O 420.1, Section 4.3, ANSI/ANS 8.1, and PRD-112 (poison requirements) apply to all evaluations.

\subsection{Methodology}

The criticality analysis methodology uses the Monte Carlo N-Particle Transport Code (MCNP) System computer program to assess the criticality potential associated with the ISG treatability study. This section describes the MCNP program and the validation of the MCNP code.

\subsection{Description of Method}

MCNP is a general purpose code for calculating the time-dependent continuous-energy transport of neutrons, photons, and/or electrons in three-dimensional geometries. The MCNP code is used for many applications, such as nuclear criticality safety, radiation shielding, fission heating, and many other nuclear-related topics. The code is used in this application to determine $\mathrm{k}_{\mathrm{eff}}$ and $\mathrm{k}_{\infty}$. The finite multiplication $\left(\mathrm{k}_{\mathrm{eff}}\right)$ is a measure of a finite system's ability to sustain a nuclear chain reaction. The infinite multiplication $\left(k_{\infty}\right)$ is a measure of an infinite system's ability to sustain a nuclear chain reaction. A system is defined as critical if $k=1$, supercritical if $k>1$, or subcritical if $k<1$.

\subsection{Validation}

According to Whalen et al., MCNP: Neutron Benchmark Problems, "The general purpose Monte Carlo transport code MCNP has been tested on criticality, pulsed sphere, and shielding neutron problem families. Results for each were compared to experimental data. MCNP successfully predicted the experimental results of all three families within the expected data and statistical uncertainties. These successful predictions demonstrate that MCNP can successfully model a broad spectrum of neutron transport problems."

The MCNP program was performed on a Hewlett-Packard Series 9000 workstation using the HP-UNIX 10.20 operating system. MCNP-4b using the ENDF/B-V cross-section data was used to calculate the results. The MCNP-4b code on the workstations is verified per company software quality assurance plans (INEEL/INT-98-01140).

The results from this CSE are intended indicate the margin of safety and are not used to set fissile mass limits. The use of neutron absorbers and validation of the results will be addressed in the final CSE.

\subsection{Discussion of Contingencies}

The double contingency principle, required by the Department of Energy (DOE), states "The double contingency principle shall be used as a minimum to ensure that a criticality accident is an extremely unlikely event. Compliance with the double contingency principle requires that two unlikely, independent, and concurrent changes in process or system conditions occur before a criticality accident is possible." (DOE O 420.1) 
For cementitious grouts consideration has been given to all credible scenarios within the ISG treatability study that could have an impact on criticality safety. There are adequate margins of safety within the nature of the cementitious operation to ensure that a criticality accident is not credible; although, the use of paraffin grouts will require additional controls. The margin of safety includes the inability of sufficient plutonium to accumulate in a favorable geometry with necessary moderation, reflection, and minimal diluent. If credit is taken for adding boron within the paraffin to reduce the moderation effects of paraffin, an adequate process must be in place to guarantee the boron remains in the paraffin at the designated concentration (that is, the boron does not leach out of the paraffin due to environmental and/or application effects). The margin of safety for this project is discussed in detail in the following section.

\subsection{Evaluation and Results}

\subsection{Evaluation}

Process knowledge and archived shipping reports indicate that the waste containers are in various stages of deterioration. The integrity of the containers may range from completely disintegrated to structurally sound. Therefore, the possibility of puncturing an overloaded drum and concentrating fissile material from the grouting operation does exist. The identified plutonium pathways resulting in the accumulation of plutonium are compaction of the waste and injecting the grout into the subsurface. A detailed discussion of each identified pathway is discussed in the following subsections.

\subsubsection{Compaction}

As the drill stem is inserted into the waste environment, the potential for the waste to become locally compacted or consolidated increases. The consolidation of the fissile mass may result in a small increase in the reactivity of the waste; however, the small diameter of the drill stem will limit the compaction/consolidation of the waste. The accumulation of fissile material within the drill stem is not of concern because the drill stem is geometrically safe (nine centimeter diameter). In addition, grouting matrix will be released from the drill stem at a positive flow while the drill stem is inserted into the subsurface.

\subsubsection{Injection}

The grouting matrix is ejected from the drill stem nozzle at a pressure of 400 bars and produces a nominal radial mixing distance of grouting matrix and waste of 29 centimeters. The drill stem is withdrawn in 5 centimeter increments and grouting matrix is injected into the waste media for approximately four to six seconds. The total nominal effected mixing volume is 13.2 liters. This volume equates to approximately $6 \%$ of a disposed drum. Therefore, there is minimal potential for plutonium migration/consolidation from injecting the grout into the subsurface.

\subsection{Assessment}

A preliminary criticality evaluation of the planned ISG treatability study assessing the criticality potential for the project has been completed to determine if a credible fissile mass can accumulate from the grouting activities. Calculations were conducted to determine a mass of plutonium to obtain a k-infinity $\left(k_{\infty}\right)$ and $k_{\text {eff }}$ of 1.00 for different grouting materials. The finite volume calculations simulated a 55-gallon drum and half of a 55-gallon drum. For conservatism, the drum volume was modeled as a sphere. The grouting materials include cementitious and paraffin products. Cementitious grouts are poor moderators whereas paraffin is an excellent moderator. Neutron poisons can be mixed with the paraffin to minimize moderation. 
Although the fissile mass contained in the subsurface pit is unknown and cannot be accurately defined, grouting scenarios can be simulated to estimate the amount of fissile mass required for criticality. Once the amount of fissile mass to create criticality is estimated, engineering judgments can be made to determine if there is sufficient fissile mass within the subsurface for a credible event.

The following sections outline the methods of criticality control evaluated for the ISG treatability study and present the results from the analysis.

\subsection{Computer Modeling Assumptions}

Assumptions required to formulate the input models for the MCNP computer code include the fissile nuclide and grout matrix. For conservative purposes, Pu-239 was assumed as the fissile nuclide. Plutonium bounds U-235 that may be disposed within the SDA. Table 3 indicates the composition of cured grout. Several different elemental concrete grouts will be used to encapsulate the waste. Of the grouts investigated for this preliminary criticality safety evaluation, the elemental composition of the grout listed in this PCSE represents the most conservative (that is, the most reactive). This is primarily due to the low iron content. The final CSE will evaluate the grouts of choice; although it is not anticipated that there is a more reactive cementitious grout matrix. Table 4 indicates the composition of the paraffin grout $\left(\mathrm{C}_{25} \mathrm{H}_{52}\right)$. The paraffin poison evaluated is Boron 10 . The density of the cured concrete grout is $2.35 \mathrm{~g} / \mathrm{cm}^{3}$. and the density of the paraffin grout is $0.93 \mathrm{~g} / \mathrm{cm}^{3}$. The moisture content of the concrete grout was varied to determine the most reactive moisture content. The nominal moisture content for this type of application is $50 \mathrm{wt} \%$ although one type of cementitious grout that will be applied has a $33 \mathrm{wt} \%$ moisture content. The plutonium was assumed to be homogeneously dispersed throughout the grouting matrix.

\section{Table 3. Composition of Concrete Grout.}

\begin{tabular}{||c|c||}
\hline Material & Mass Fraction \\
\hline $\mathrm{H}$ & 0.0056 \\
\hline $\mathrm{O}$ & 0.4956 \\
\hline $\mathrm{Si}$ & 0.3135 \\
\hline $\mathrm{Al}$ & 0.0456 \\
\hline $\mathrm{Na}$ & 0.0171 \\
\hline $\mathrm{Ca}$ & 0.0826 \\
\hline $\mathrm{Fe}$ & 0.0122 \\
\hline $\mathrm{K}$ & 0.0192 \\
\hline $\mathrm{Mg}$ & 0.0024 \\
\hline $\mathrm{S}$ & 0.0012 \\
\hline
\end{tabular}


Table 4. Compositions of Paraffin Grout.

\begin{tabular}{|c|c|}
\hline Material & Mass Fraction \\
\hline C & 0.8514 \\
\hline H & 0.1486 \\
\hline
\end{tabular}

An infinite system of both grouting materials was modeled to achieve the most conservative plutonium concentration within the grouting matrix. In addition, spheres (208, and 104 liters) were also modeled to determine a finite plutonium concentration.

\subsection{Results}

Neutron multiplication factor $k_{\text {eff }}$ and $k_{\infty}$ were calculated for the two grouting materials to determine the minimum concentration of plutonium to obtain a k-effective and k-infinity of 1.00 . The finite arrays were modeled with 24 inches of reflection with the respective grouting medium (concrete or paraffin). The 24 inches of reflection represents a near infinite reflective system. The results of the computer calculations are given in Table 5 and Table 6 . The calculations were generated to determine the mass of plutonium necessary for a criticality.

Table 5 represents the infinite and finite concrete matrix computer results. The first (Case Number) column indicates the MCNP input deck filename. The second (Water Percent) column provides the mass fraction of water. The third (Pu Density) column represents the critical plutonium concentration. The fourth (Finite Pu Mass) column designates the finite mass required for a criticality event (only given for the finite cases). The fifth $(\mathrm{H} / \mathrm{Pu})$ column indicates the hydrogen to plutonium ratio within the grouting matrix. The sixth $\left(\mathrm{k}_{\text {inf }} \pm 2 \sigma\right)$ column lists the multiplication factor and two standard deviations. 
Table 5. Concrete Matrix Results.

\begin{tabular}{|c|c|c|l|c|c|}
\hline \multicolumn{5}{|c|}{ Concrete Matrix } \\
\hline Case \# & $\begin{array}{c}\text { Water Percent } \\
(\mathrm{wt} \%)\end{array}$ & $\begin{array}{c}\text { Pu Density } \\
\left(\mathrm{g} / \mathrm{cm}^{3}\right)\end{array}$ & $\begin{array}{c}\mathrm{H} / \mathrm{Pu} \\
(\mathrm{a} \%)\end{array}$ & $\mathrm{k}_{\text {inf }} \pm 2 \sigma$ \\
\hline Conc1 & 50 & 0.0063 & & 3,092 & $0.9925 \pm 0.0006$ \\
\hline Conc & 30 & 0.0052 & & 2,850 & $0.9952 \pm 0.0006$ \\
\hline Conc2 & 10 & 0.0040 & 1,982 & $0.9923 \pm 0.0008$ \\
\hline \multicolumn{5}{|c|}{ Finite Volume 208 Liters (55-gallons) } \\
\hline Case \# & $\begin{array}{c}\text { Water Percent } \\
(\mathrm{wt} \%)\end{array}$ & $\begin{array}{c}\text { Pu Density } \\
\left(\mathrm{g} / \mathrm{cm}^{3}\right)\end{array}$ & $\begin{array}{c}\text { Finite } \mathrm{Pu} \\
\text { Mass }(\mathrm{g})\end{array}$ & $\mathrm{H} / \mathrm{Pu}$ & $\mathrm{k}_{\text {eff }} \pm 2 \sigma$ \\
\hline Drum1 & 50 & 0.0097 & 2,020 & 2,008 & $1.0005 \pm 0.0016$ \\
\hline Drum & 30 & 0.0100 & 2,080 & 1,527 & $1.0019 \pm 0.0020$ \\
\hline Drum2 & 10 & 0.0118 & 2,450 & 672 & $1.0039 \pm 0.0024$ \\
\hline \multicolumn{5}{|c|}{ Finite Volume 104 Liters } \\
\hline Case \# & $\begin{array}{c}\text { Water Percent } \\
(\mathrm{wt} \%)\end{array}$ & $\begin{array}{c}\text { Pu Density } \\
\left(\mathrm{g} / \mathrm{cm}^{3}\right)\end{array}$ & $\begin{array}{c}\text { Finite Pu } \\
\text { Mass }(\mathrm{g})\end{array}$ & $\mathrm{H} / \mathrm{Pu}$ & $\mathrm{k}_{\text {eff }} \pm 2 \sigma$ \\
\hline Drum11 & 50 & 0.0121 & 1,260 & 1,610 & $1.0003 \pm 0.0020$ \\
\hline Drum0 & 30 & 0.0131 & 1,360 & 1,131 & $1.0041 \pm 0.0032$ \\
\hline Drum22 & 10 & 0.0212 & 2,200 & 374 & $1.0033 \pm 0.0028$ \\
\hline
\end{tabular}

The results from Table 5 indicate that an infinite system with cured grout (10\% moisture content) is the most reactive. The most reactive finite volume is the moist grout (50\% moisture content). In addition, the results indicate that a smaller volume (104 liters) requires less fissile mass for a critical system than a larger volume (55-gal). The plutonium mass required for a criticality in the smaller volume (104 liters) is 1,260 grams. Also, the results indicate that the plutonium concentration increases as the volume decreases; this is due to neutron leakage. Parametric studies for the concrete matrix infinite and finite systems can be found in Appendix C.

Table 6 represents the infinite and finite paraffin matrix computer results. The first (Case Number) column indicates the MCNP input deck filename. The second (Boron Percent) column provides the mass fraction of boron in the paraffin grout. The third (Pu Density) column represents the critical plutonium concentration. The fourth $(\mathrm{H} / \mathrm{Pu})$ column indicates the hydrogen to plutonium ratio within the grouting matrix. The fifth (Finite Pu Mass) column designates the finite mass required for a criticality event. The sixth $\left(k_{\text {inf }} \pm 2 \sigma\right)$ column lists the multiplication factor and two standard deviations. 
Table 6. Paraffin Matrix Results

\begin{tabular}{|c|c|c|c|c|c|}
\hline \multicolumn{5}{|c|}{ Paraffin Matrix } \\
\hline Case \# & $\begin{array}{c}\text { Boron Percent } \\
(\mathrm{wt} \%)\end{array}$ & $\begin{array}{c}\text { Pu Density } \\
\left(\mathrm{g} / \mathrm{cm}^{3}\right)\end{array}$ & $\begin{array}{c}\mathrm{H} / \mathrm{Pu} \\
(\mathrm{a} \%)\end{array}$ & $\mathrm{k}_{\text {inf }} \pm 2 \sigma$ \\
\hline Paraffwo & $\mathrm{N} / \mathrm{A}$ & 0.0097 & & 3,378 & $0.9998 \pm 0.0006$ \\
\hline Paraff1\% & $1.060 \mathrm{E}-04$ & 0.0097 & 3,378 & $0.7406 \pm 0.0010$ \\
\hline \multicolumn{7}{|c|}{ Finite Volume 208 Liters } \\
\hline Case \# & $\begin{array}{c}\text { Boron Percent } \\
(\mathrm{wt} \%)\end{array}$ & $\begin{array}{c}\text { Pu Density } \\
\left(\mathrm{g} / \mathrm{cm}^{3}\right)\end{array}$ & $\begin{array}{c}\text { Finite } \mathrm{Pu} \\
\text { Mass }(\mathrm{g})\end{array}$ & $\mathrm{H} / \mathrm{Pu}$ & $\mathrm{k}_{\text {eff }} \pm 2 \sigma$ \\
\hline Drum3 & N/A & 0.01125 & 2,340 & 2,913 & $0.9976 \pm 0.0012$ \\
\hline Drum4 & $\begin{array}{c}1.062 \mathrm{E}-04 \\
0.01125\end{array}$ & 2,340 & 2,913 & $0.7490 \pm 0.0014$ \\
\hline Case \# & $\begin{array}{c}\text { Boron Percent } \\
(\mathrm{wt} \%)\end{array}$ & $\begin{array}{c}\text { Pu Density } \\
\left(\mathrm{g} / \mathrm{cm}^{3}\right)\end{array}$ & $\begin{array}{c}\text { Finite Pu } \\
\text { Mass }(\mathrm{g})\end{array}$ & $\mathrm{H} / \mathrm{Pu}$ & $\mathrm{k}_{\text {eff }} \pm 2 \sigma$ \\
\hline Drum33 & N/A & 0.0128 & 1,330 & 2,560 & $1.0005 \pm 0.0016$ \\
\hline Drum44 & $1.061 \mathrm{E}-04$ & 0.0128 & 1,330 & 2,560 & $0.7692 \pm 0.0016$ \\
\hline
\end{tabular}

The results from Table 6 indicate that the finite volume representing half of a nominal disposal drum volume (104 liters) is more reactive. The required plutonium mass to create a criticality for the smaller volume (104 liters) is 1,330 grams. The plutonium density increases as the volume decreases; this is due to neutron leakage. Parametric studies for the paraffin matrix infinite and finite systems can be found in Appendix C.

\subsection{Discussion of Results}

The results indicate a large quantity of homogeneously mixed plutonium in the grouting matrix is required to create a criticality event. The concrete moisture content was varied to represent the conditions that will be experienced within the SDA. The $50 \%$ moisture content represents the nominal moisture content at which the grout will be injected into the subsurface. The $30 \%$ moisture content represents one type of grout that will be used, and the $10 \%$ moisture content represents a cured grout. The computer modeling results for the finite scenario indicate that the $50 \%$ moisture content is the most reactive. The required unsafe mass of plutonium for a finite volume (104 liters) to create a criticality event is 1,260 grams.

Scenarios were also calculated for the paraffin grouts that will be used to encapsulate the buried waste. The required unsafe plutonium mass for the paraffin grout for a finite volume (104 liters) to create a criticality event is 1,330 grams. However, if boron $(B-10)$ is added $(0.0001 \mathrm{~g} / \mathrm{cc})$ within the paraffin, the plutonium mass to create a criticality event is greatly increased.

As the plutonium is dispersed homogeneously over the entire volume, of the drum, the system becomes overmoderated. There probably is no mechanism to homogeneously distribute the plutonium throughout the volume of a drum, the grout is most likely going to fill the voids within the waste contained in a drum. As the volume of the system is decreased, the mass of plutonium necessary to achieve a critical system decreases. This is due to the system shifting from an overmoderated system to an optimally moderated system. For plutonium paraffin 
systems, the optimum H/Pu ratio occurs in the range of 500 to 700 , depending upon the chosen reflector conditions. At these optimum moderation points, it should be noted that much less plutonium would be necessary to achieve a critical system: on the order of 400 to 500 grams. These optimally moderated systems are not likely to be achieved in the in-situ grouting process. Benchmark in-situ tests will indicate whether the paraffin will be dispersed evenly within the fissile material within "heterogeneous" areas of the waste matrix or the grouting process will tend to isolate these areas. The final CSE will address the results of the benchmark experiments and determine the realistic system for ISG stabilization. Finally, the scenarios assessed for this evaluation do no take credit for waste debris/diluent within the drums.

\subsection{Design Features and Administratively Controlled Limits \& Requirements}

The following controls have been identified during this criticality safety evaluation. These controls are required to ensure criticality safety during probing operations in the SDA. Additional administrative and engineering controls may be identified for each probing campaign.

\subsection{Grouting Operations}

\subsubsection{Administrative Controls}

1. Preliminary calculations show that boron added to paraffin grouting matrix at a concentration of $1.00 \mathrm{~g} / \mathrm{l}$ will have adequate criticality control.

\subsubsection{Engineering Controls}

At this time no engineering controls have been identified.

\subsection{Summary \& Conclusions}

This preliminary criticality evaluation assesses the criticality potential of in situ grouting in the SDA. These analyses evaluate the criticality potential of injecting grout matrices into the SDA. Based on the analyses presented in this preliminary criticality safety evaluation, there are no criticality hazards from injecting cementitious grouting matrices within the SDA. The identified fissile mass with adequate moderation necessary for a criticality hazard, along with engineering and administrative controls identified by this evaluation, indicate that a criticality event will not occur under normal or postulated abnormal conditions.

Although this is a preliminary criticality safety evaluation, the data and results should not be viewed as preliminary. This evaluation is viewed as preliminary primarily based on the unknown results of plutonium migration (if any) from grout injection and whether the grouting materials can maintain boron concentrations at predetermined levels.

Finally, if boron is used as a poison, a process to measure boron concentration prior to insertion and an evaluation showing boron will remain homogeneously distributed within the paraffin under all environmental conditions is required. 


\subsection{References}

Acid Pit Stabilization Project, INEEL/EXT-98-00009, December 1998.

Criticality Safety Program Requirements Manual, PRD-112 Rev 1.

Daniel J. Whalen, David A. Cardon, Jennifer L. Uhle, and John S. Hendricks, MCNP: Neutron Benchmark Problems, Los Alamos National Laboratory, New Mexico, November 1991, LA12212.

Guy G. Loomus, et. al., Inovative Subsurface Stabilization Project - Final Report, INEL-96/0439, Rev 1, July 1997.

Guy G. Loomus, Jim Jessmore., In-Situ Buried Waste Stabilization Technologies at the Idaho National Engineering and Environmental Laboratory. Radwaste Magazine, July 1998 pgs 39-43.

L. V. East, Suspect Drum TRU Mass Characterization, RWMC-EDF-800, INEL-95/024, March 9, 1995.

Nuclear Criticality Safety in Operations with Fissionable Materials Outside Reactors, American National Standards Institute/American Nuclear Society, LaGrange Park, Illinois, ANSI/ANS-8.11998.

Paxton, H.C., and N.L. Pruvost, July 1987, Critical Dimensions of Systems Containing ${ }^{235} U$, ${ }^{239} \mathrm{Pu}$, and ${ }^{233} \mathrm{U}$, 1986 Revision, Los Alamos National Laboratory, LA-10860-MS.

Software Quality Assurance Plan For MCNP4A and MCNP4B2, INEEL/INT-98-01140, January 28, 2000.

Thomas, Waste Contents Associated with OU 7-10 Stages I/II Activities in Pit 9, RWT-01-99.

Thomas L. Clements Jr., Content Code Assessments for INEL Contact-Handled Stored Transuranic Wastes, WM-F1-82-021, Idaho National Engineering Laboratory, October 1982.

U. S. Department of Energy, Order 420.1, Section 4.3, Facility Safety, October 13, 1995. 


\section{Appendix A}

Table 7A. Concrete Atom Densities

\begin{tabular}{|c|c|}
\hline Isotope or Element & Atoms/b-cm \\
\hline $\mathrm{Pu}-239$ & $2.4441-05$ \\
\hline $\mathrm{H}$ & $4.90088-02$ \\
\hline $\mathrm{O}$ & $3.6418-02$ \\
\hline $\mathrm{Si}$ & $4.7003-03$ \\
\hline $\mathrm{Al}$ & $7.1166-04$ \\
\hline $\mathrm{Na}$ & $3.1321-04$ \\
\hline $\mathrm{Ca}$ & $8.6781-04$ \\
\hline $\mathrm{Fe}$ & $9.1988-05$ \\
\hline $\mathrm{L}$ & $2.0678-04$ \\
\hline $\mathrm{Mg}$ & $4.580-05$ \\
\hline $\mathrm{S}$ & $1.5761-06$ \\
\hline
\end{tabular}

A plutonium concentration of 0.0097 was used to calculate the plutonium atom densities.

Table 8A. Paraffin Atom Densities

\begin{tabular}{|c|c|}
\hline Isotope or Element & Atoms/b-cm \\
\hline Pu-239 & $2.8346-05$ \\
\hline C & $3.9699-02$ \\
\hline H & $8.2571-02$ \\
\hline
\end{tabular}




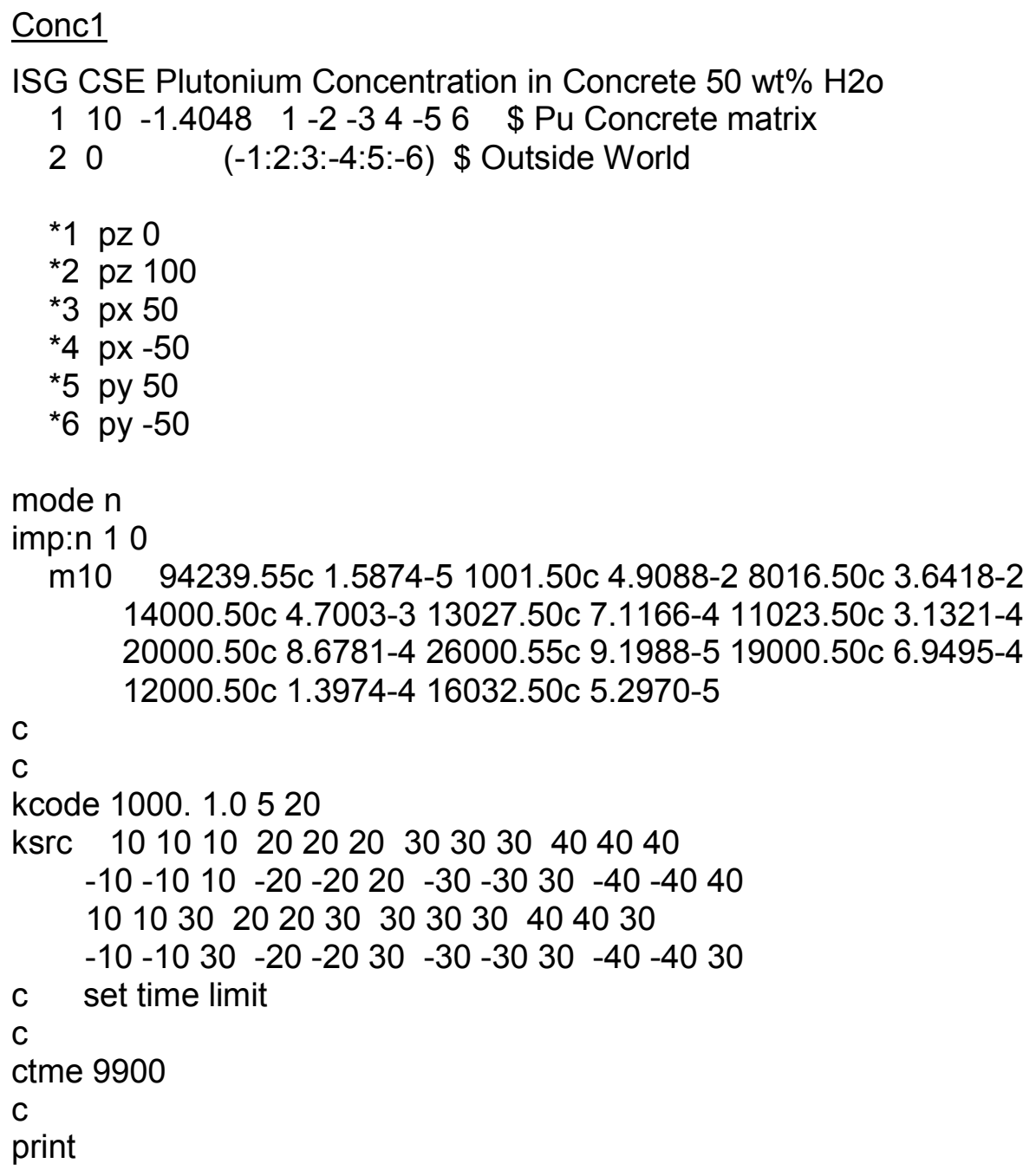




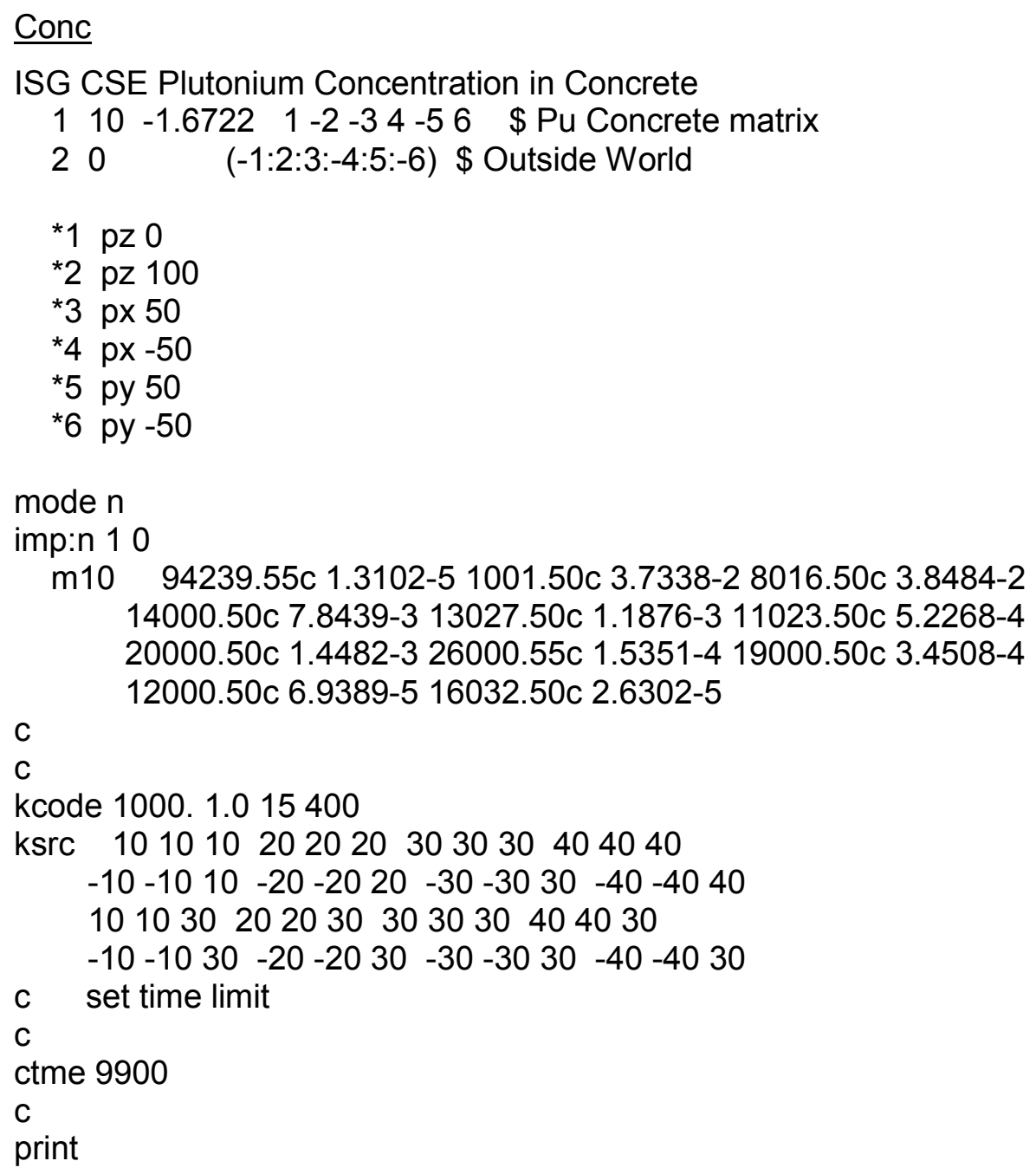




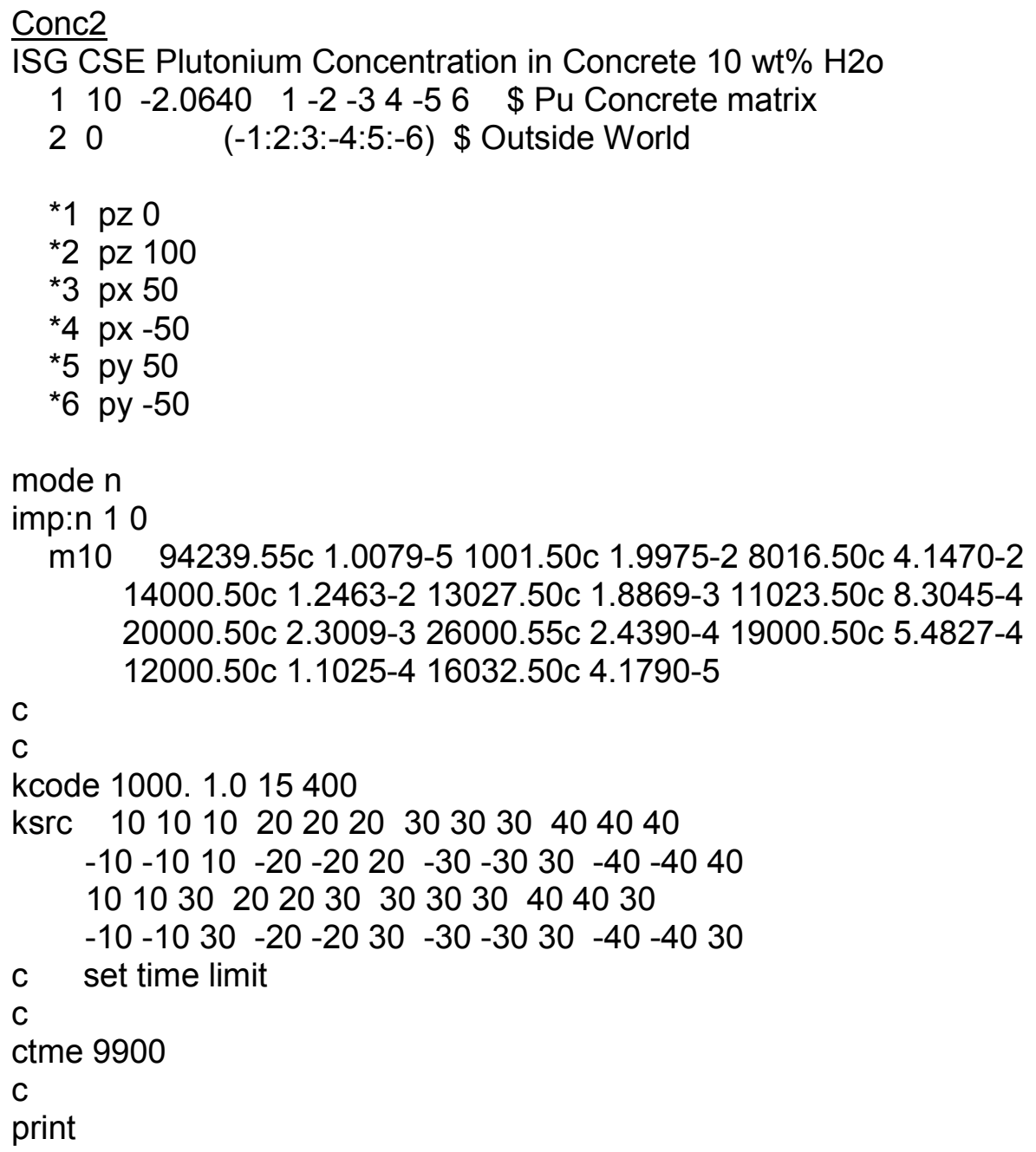




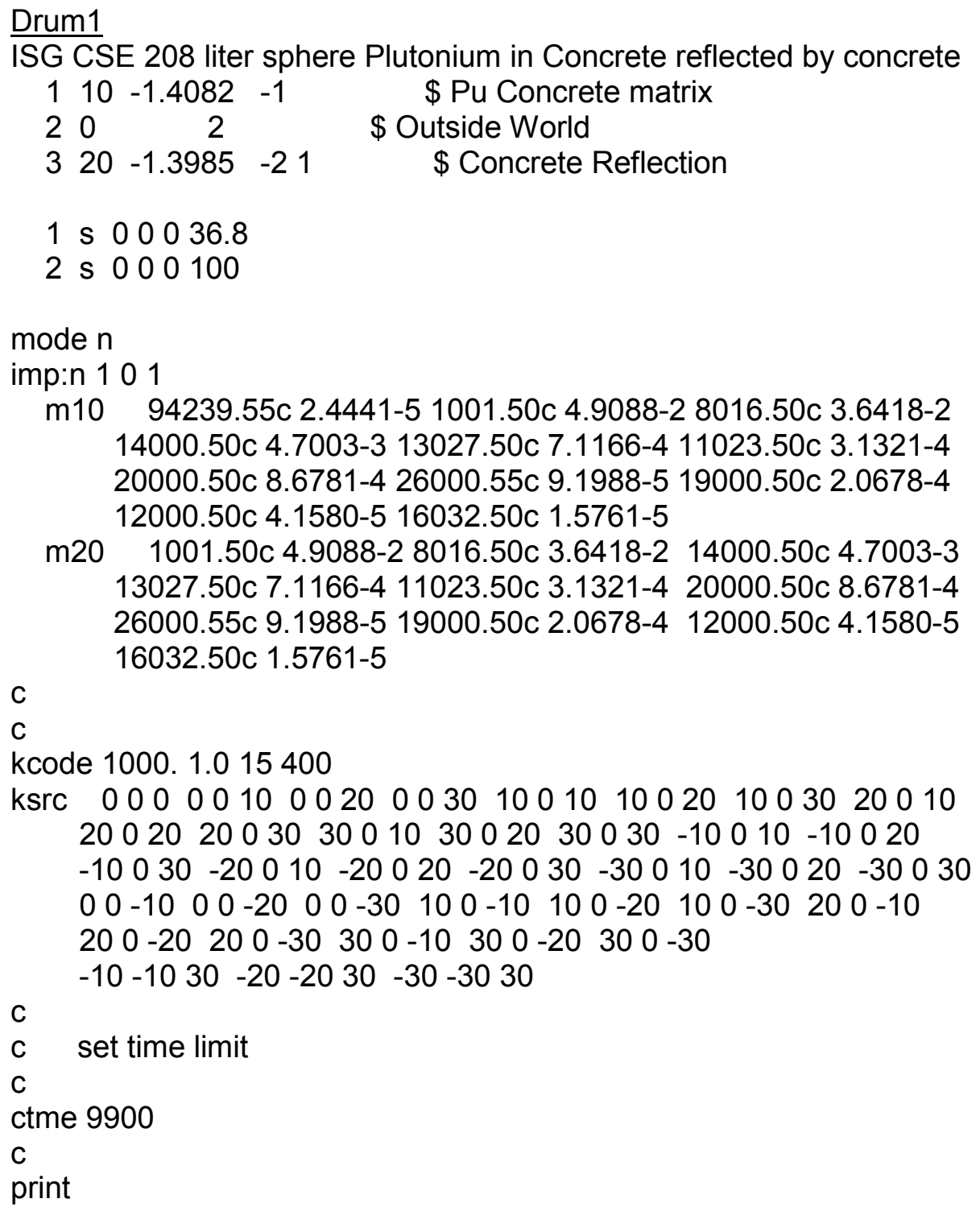




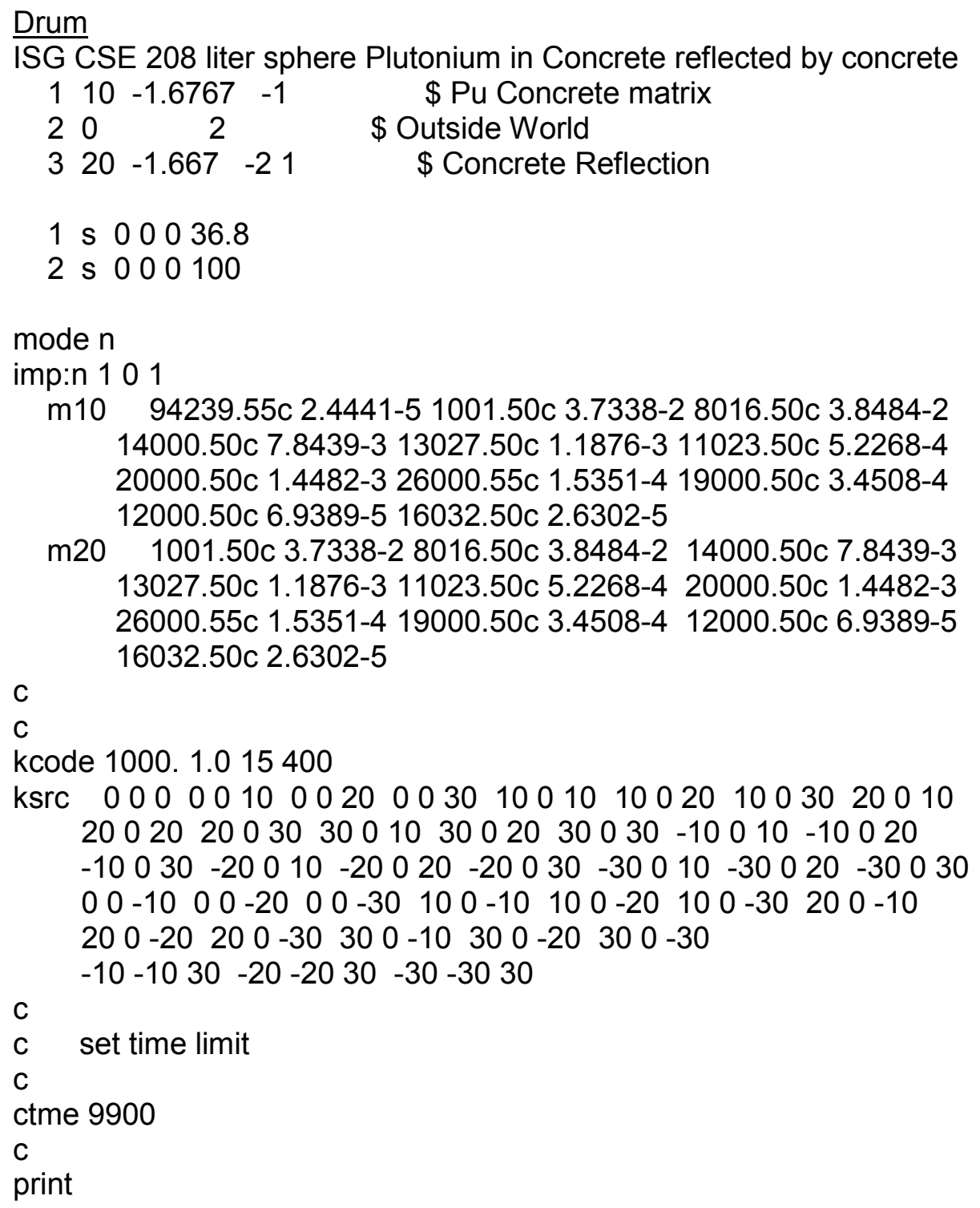









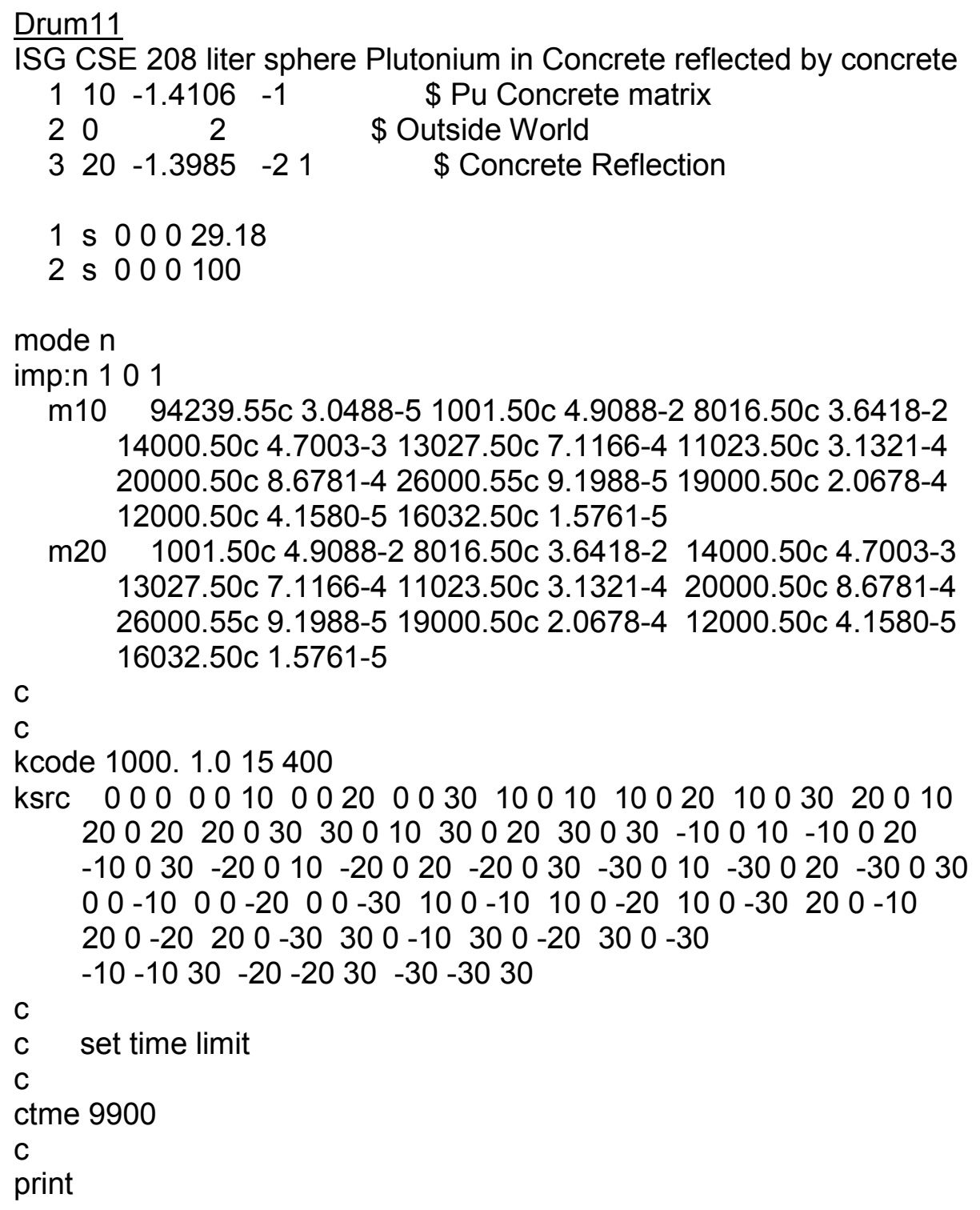




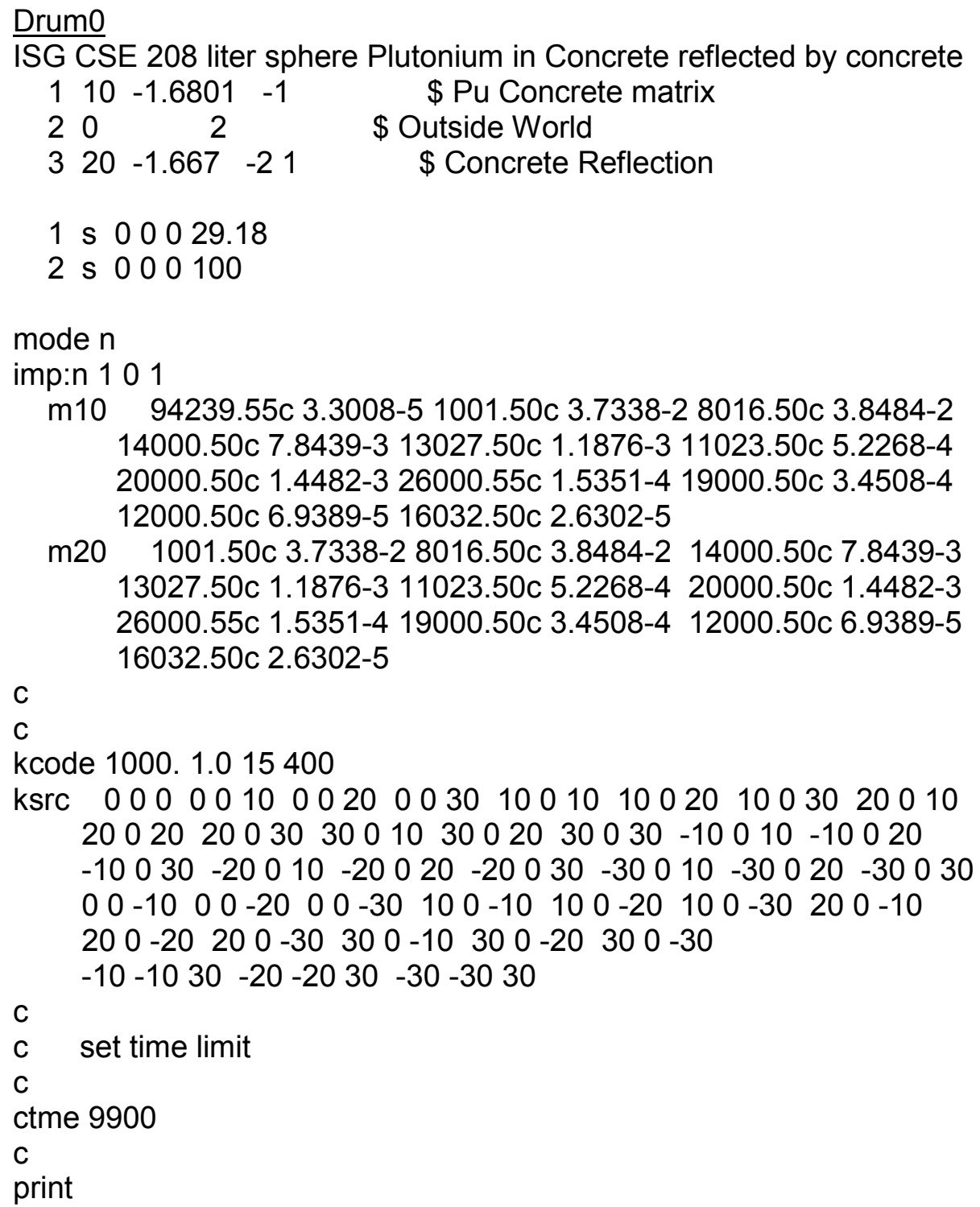




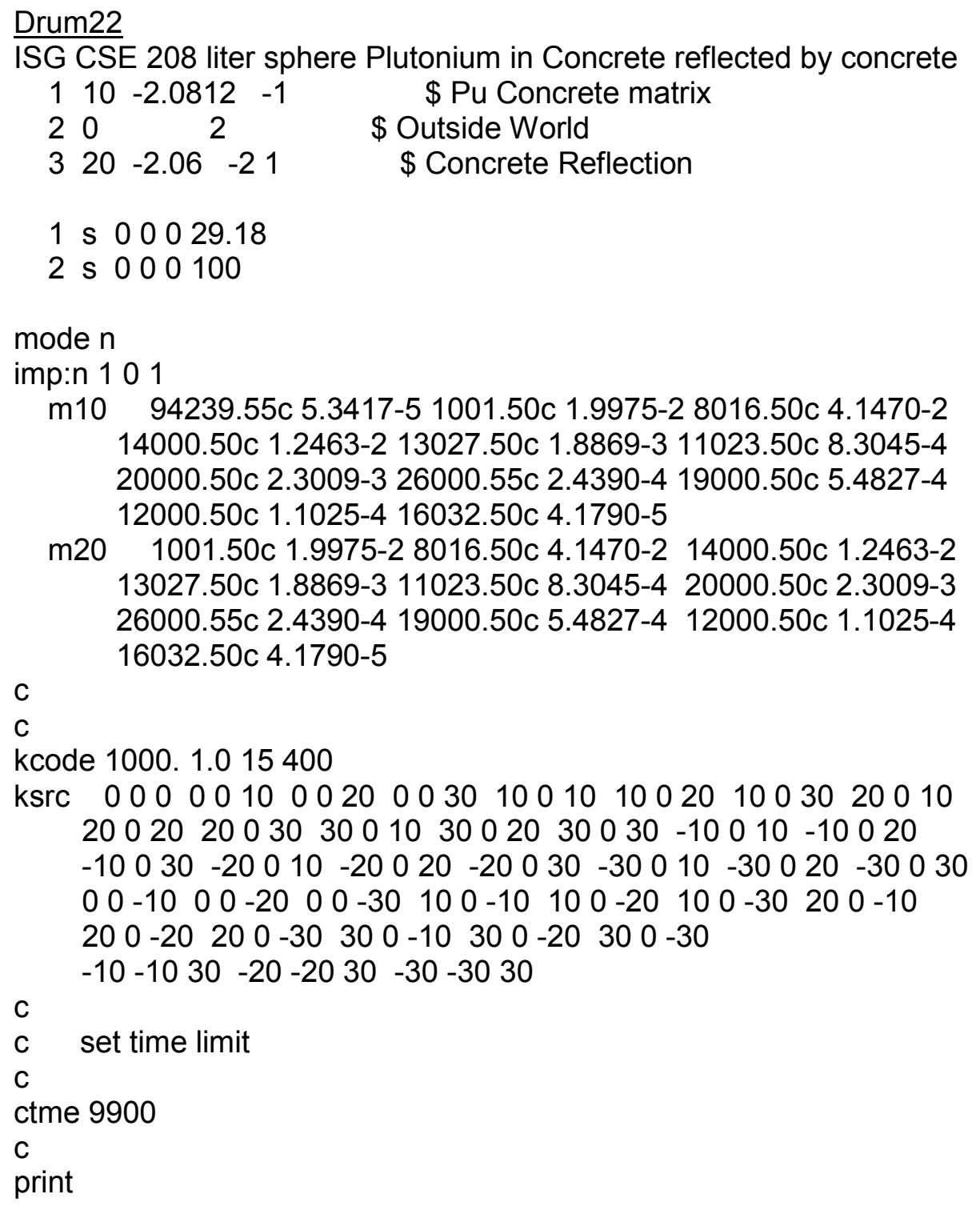




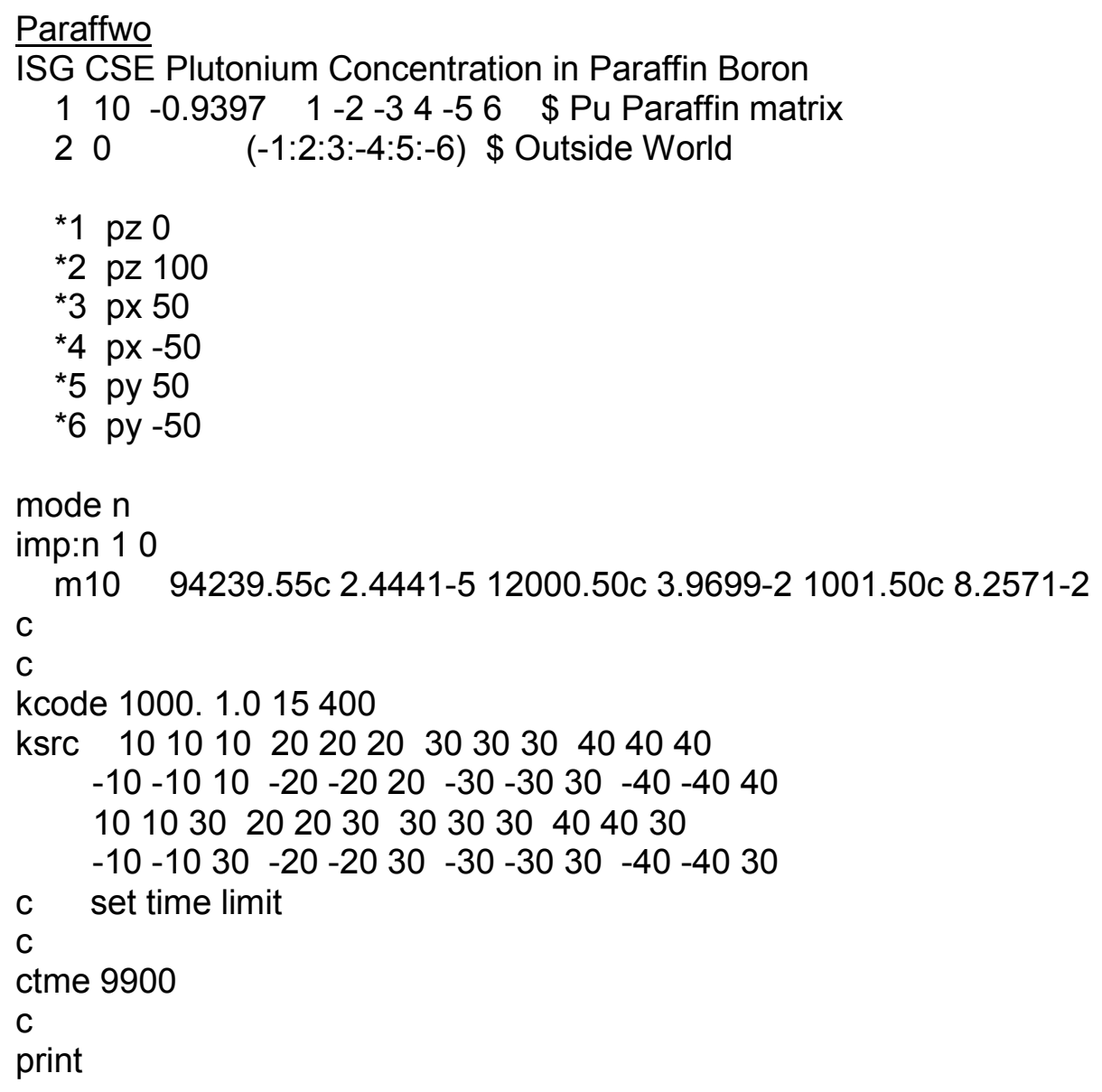




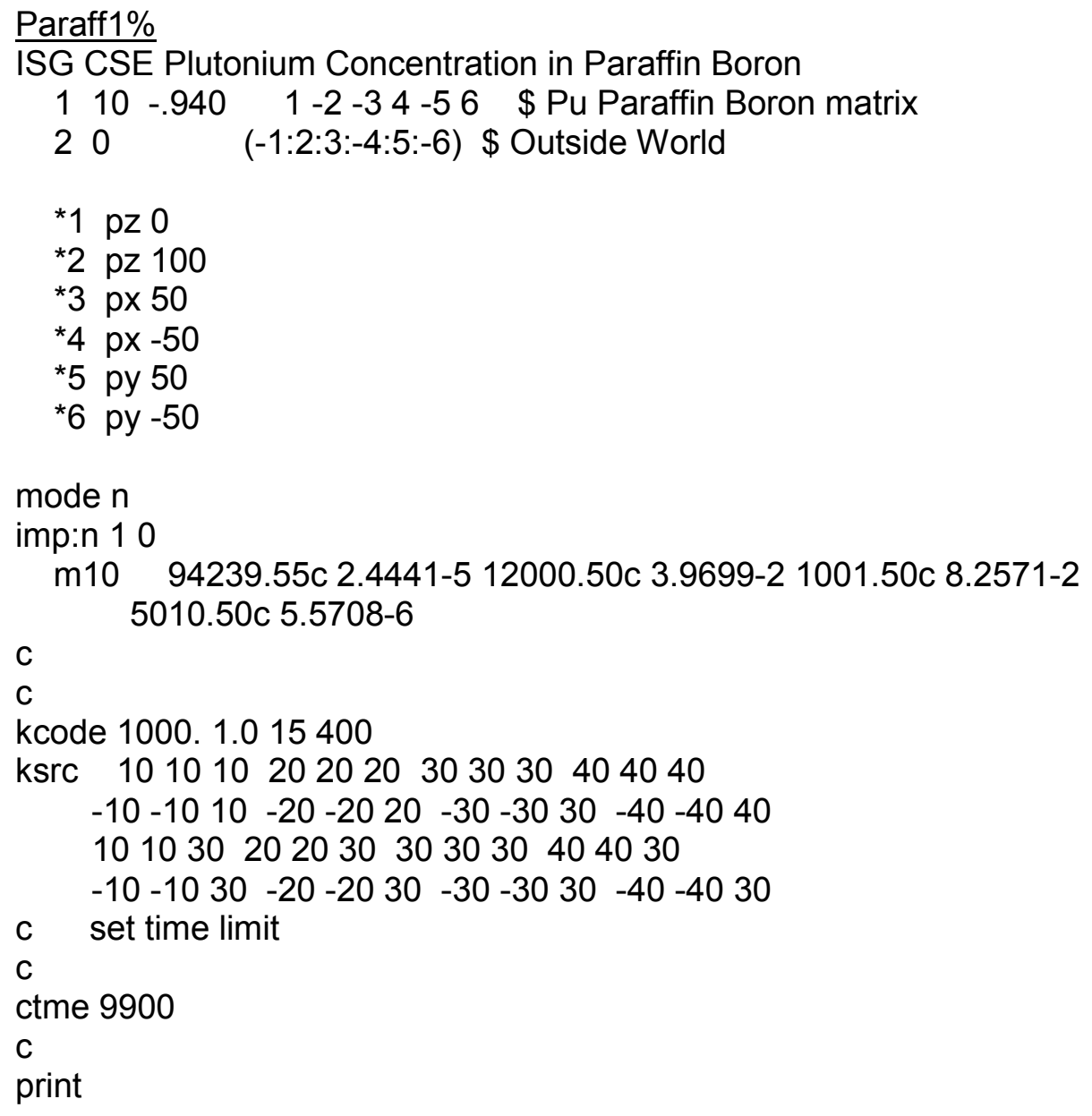




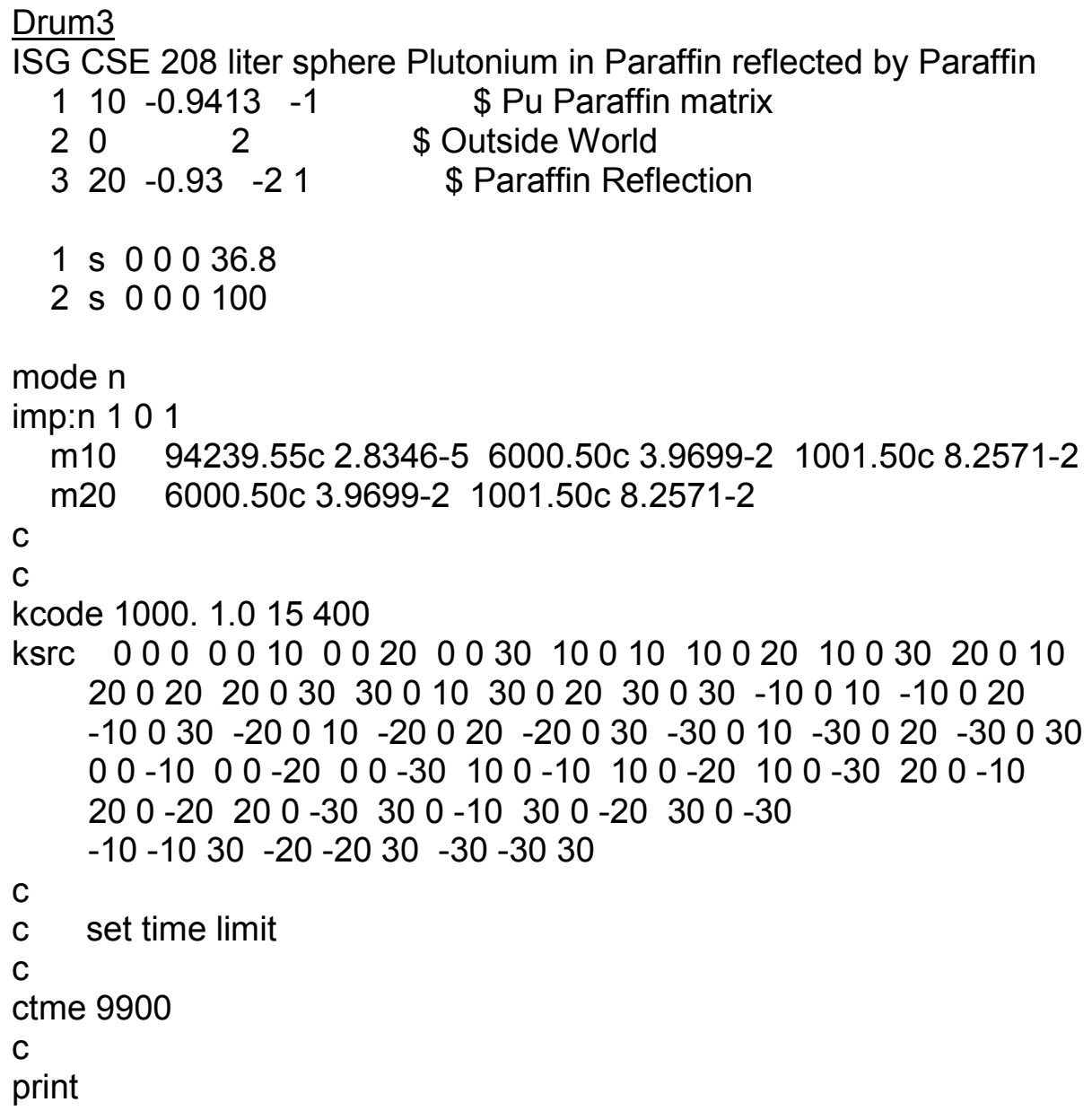




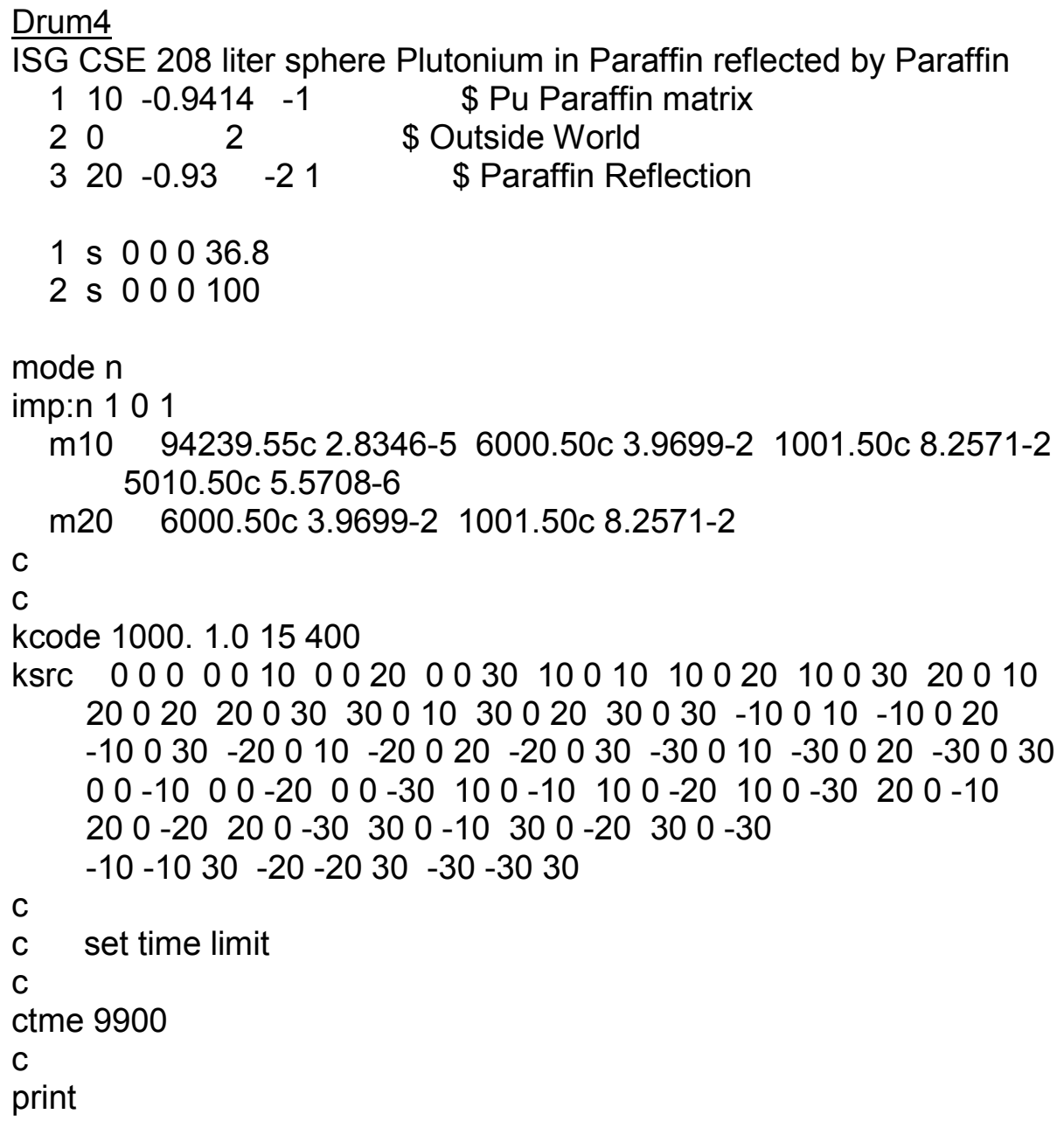














\section{Appendix C}

Table 9C. Infinite Concrete Parametric Study

\begin{tabular}{|c|c|}
\hline \multicolumn{2}{|c|}{$50 \%$ Moisture Content } \\
\hline Pu Concentration in Concrete (g/cc) & $\mathrm{k}_{\mathrm{eff}} \pm \sigma$ \\
\hline 0.0083 & $1.1332 \pm 0.0004$ \\
\hline 0.0073 & $1.0676 \pm 0.0004$ \\
\hline 0.0063 & $0.9925 \pm 0.0003$ \\
\hline 0.0053 & $0.9035 \pm 0.0004$ \\
\hline 0.0043 & $0.7985 \pm 0.0003$ \\
\hline \multicolumn{2}{|c|}{$30 \%$ Moisture Content } \\
\hline Pu Concentration in Concrete (g/cc) & $\mathrm{k}_{\mathrm{eff}} \pm \sigma$ \\
\hline 0.0072 & $1.1609 \pm 0.004$ \\
\hline 0.0062 & $1.0849 \pm 0.004$ \\
\hline 0.0052 & $0.9952 \pm 0.0003$ \\
\hline 0.0042 & $0.8855 \pm 0.0003$ \\
\hline 0.0032 & $0.7510 \pm 0.0003$ \\
\hline \multicolumn{2}{|c|}{$10 \%$ Moisture Content } \\
\hline Pu Concentration in Concrete (g/cc) & $k_{\text {eff }} \pm \sigma$ \\
\hline 0.006 & $1.2109 \pm 0.0004$ \\
\hline 0.005 & $1.1213 \pm 0.0004$ \\
\hline 0.004 & $1.0041 \pm 0.0004$ \\
\hline 0.003 & $0.8626 \pm 0.0004$ \\
\hline 0.002 & $0.6691 \pm 0.0003$ \\
\hline
\end{tabular}

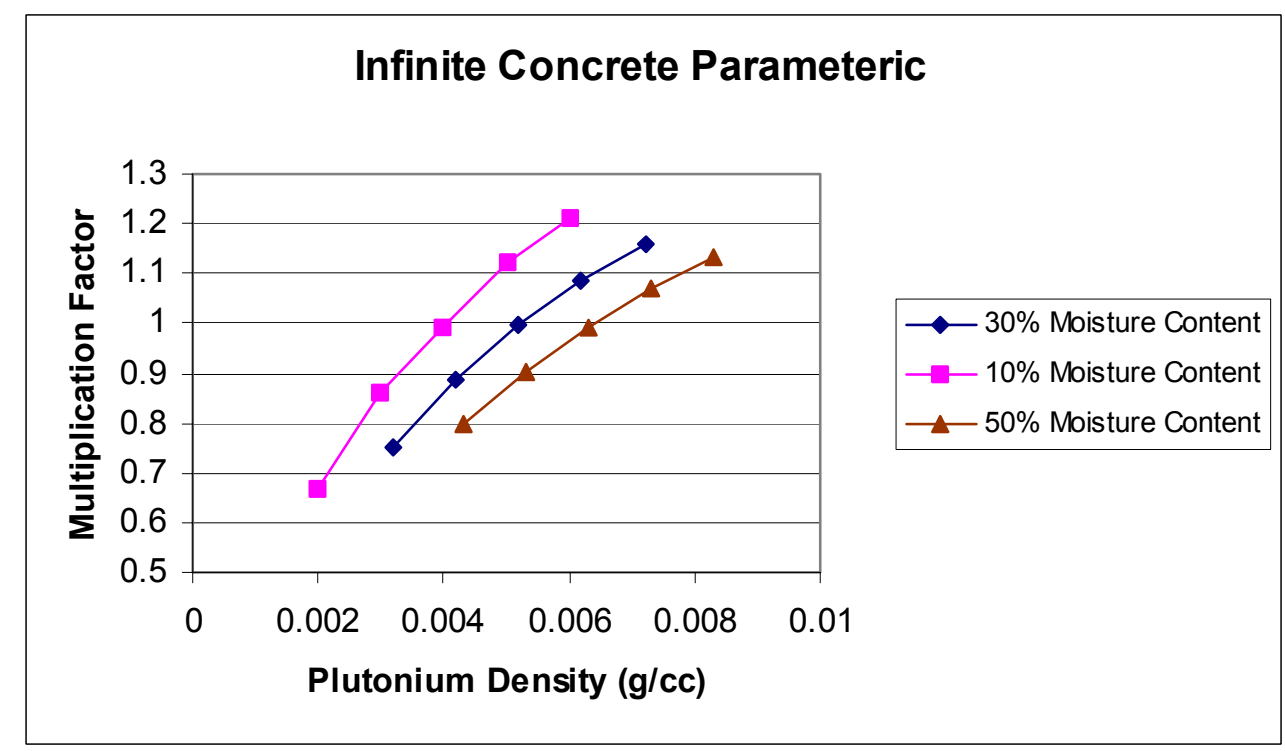

Figure 3C. Infinite Concrete Parametric Study. 
Table 10C. Finite (208 Liter) Concrete Parameter Study.

\begin{tabular}{|c|c|}
\hline \multicolumn{2}{|c|}{$50 \%$ Moisture Content } \\
\hline Pu Concentration in Concrete $(\mathrm{g} / \mathrm{cc})$ & $\mathrm{k}_{\text {eff }} \pm \sigma$ \\
\hline 0.0117 & $1.0779 \pm 0.0009$ \\
\hline 0.0107 & $1.0437 \pm 0.0009$ \\
\hline 0.0097 & $1.0005 \pm 0.0009$ \\
\hline 0.0087 & $0.9535 \pm 0.0008$ \\
\hline 0.0077 & $0.9014 \pm 0.0008$ \\
\hline \multicolumn{2}{|c|}{$30 \%$ Moisture Content } \\
\hline Pu Concentration in Concrete $(\mathrm{g} / \mathrm{cc})$ & $\mathrm{k}_{\mathrm{eff}} \pm \sigma$ \\
\hline 0.0117 & $1.0751 \pm 0.0010$ \\
\hline 0.0107 & $1.0409 \pm 0.0010$ \\
\hline 0.0097 & $1.0019 \pm 0.0010$ \\
\hline 0.0087 & $0.9574 \pm 0.0010$ \\
\hline 0.0077 & $0.9075 \pm 0.0012$ \\
\hline \multicolumn{2}{|c|}{$10 \%$ Moisture Content } \\
\hline Pu Concentration in Concrete (g/cc) & $\mathrm{k}_{\mathrm{eff}} \pm \sigma$ \\
\hline 0.0138 & $1.0480 \pm 0.0013$ \\
\hline 0.128 & $1.0275 \pm 0.0012$ \\
\hline 0.118 & $1.0039 \pm 0.0012$ \\
\hline 0.0108 & $0.9746 \pm 0.0011$ \\
\hline 0.0098 & $0.9437 \pm 0.0012$ \\
\hline
\end{tabular}

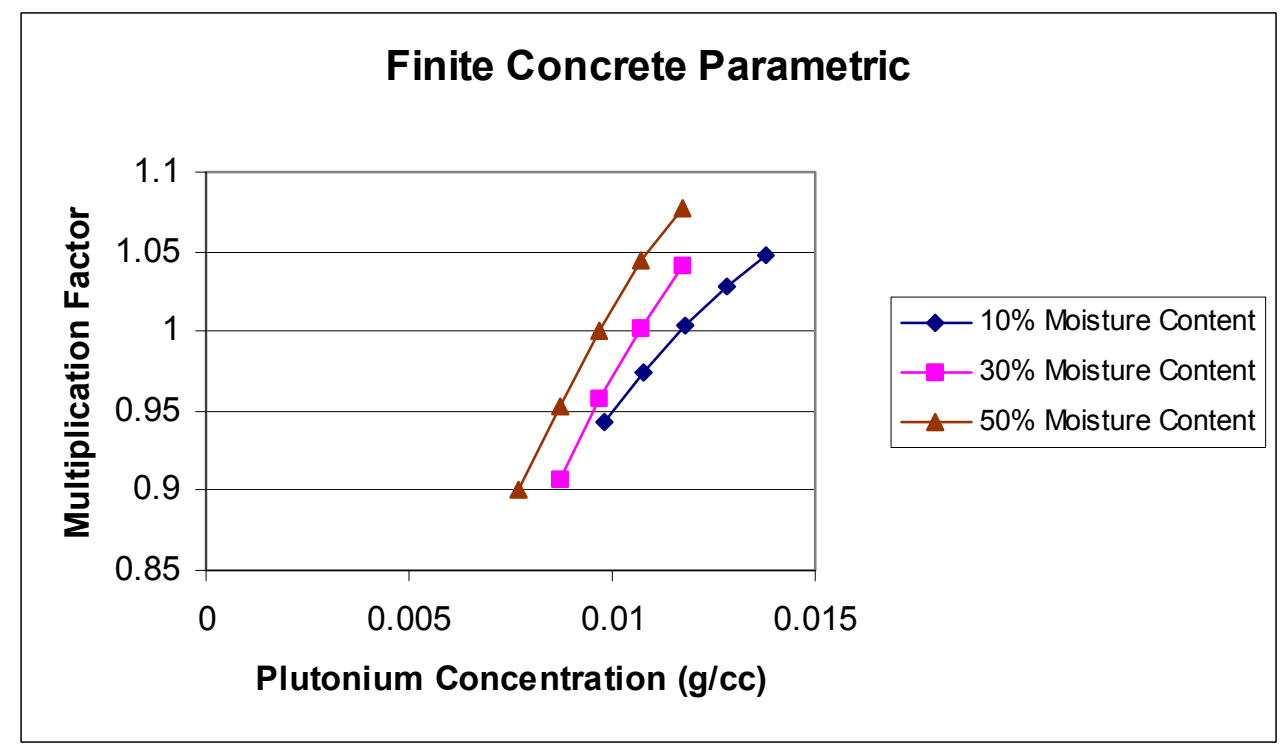

Figure 4C. Finite (208 Liter) Concrete Parametric Study. 
Table 11C. Finite (104 Liter) Concrete Parametric Study.

\begin{tabular}{|c|c|}
\hline \multicolumn{2}{|c|}{$50 \%$ Moisture Content } \\
\hline Pu Concentration in Concrete $(\mathrm{g} / \mathrm{cc})$ & $\mathrm{k}_{\text {eff }} \pm \sigma$ \\
\hline 0.0141 & $1.0579 \pm 0.0010$ \\
\hline 0.0131 & $1.0273 \pm 0.0011$ \\
\hline 0.0121 & $1.0003 \pm 0.0010$ \\
\hline 0.0111 & $0.9641 \pm 0.0010$ \\
\hline 0.0101 & $0.9281 \pm 0.0009$ \\
\hline \multicolumn{2}{|c|}{$30 \%$ Moisture Content } \\
\hline Pu Concentration in Concrete $(\mathrm{g} / \mathrm{cc})$ & $\mathrm{k}_{\mathrm{eff}} \pm \sigma$ \\
\hline 0.0151 & $1.0521 \pm 0.0011$ \\
\hline 0.0141 & $1.0305 \pm 0.0011$ \\
\hline 0.0131 & $1.0041 \pm 0.0016$ \\
\hline 0.0121 & $0.9773 \pm 0.0011$ \\
\hline 0.0111 & $0.9448 \pm 0.0011$ \\
\hline \multicolumn{2}{|c|}{$10 \%$ Moisture Content } \\
\hline Pu Concentration in Concrete (g/cc) & $\mathrm{k}_{\mathrm{eff}} \pm \sigma$ \\
\hline 0.0232 & $1.0206 \pm 0.0013$ \\
\hline 0.0222 & $1.0135 \pm 0.0013$ \\
\hline 0.0212 & $1.0033 \pm 0.0014$ \\
\hline 0.0202 & $0.9964 \pm 0.0013$ \\
\hline 0.0192 & $0.9843 \pm 0.0013$ \\
\hline
\end{tabular}

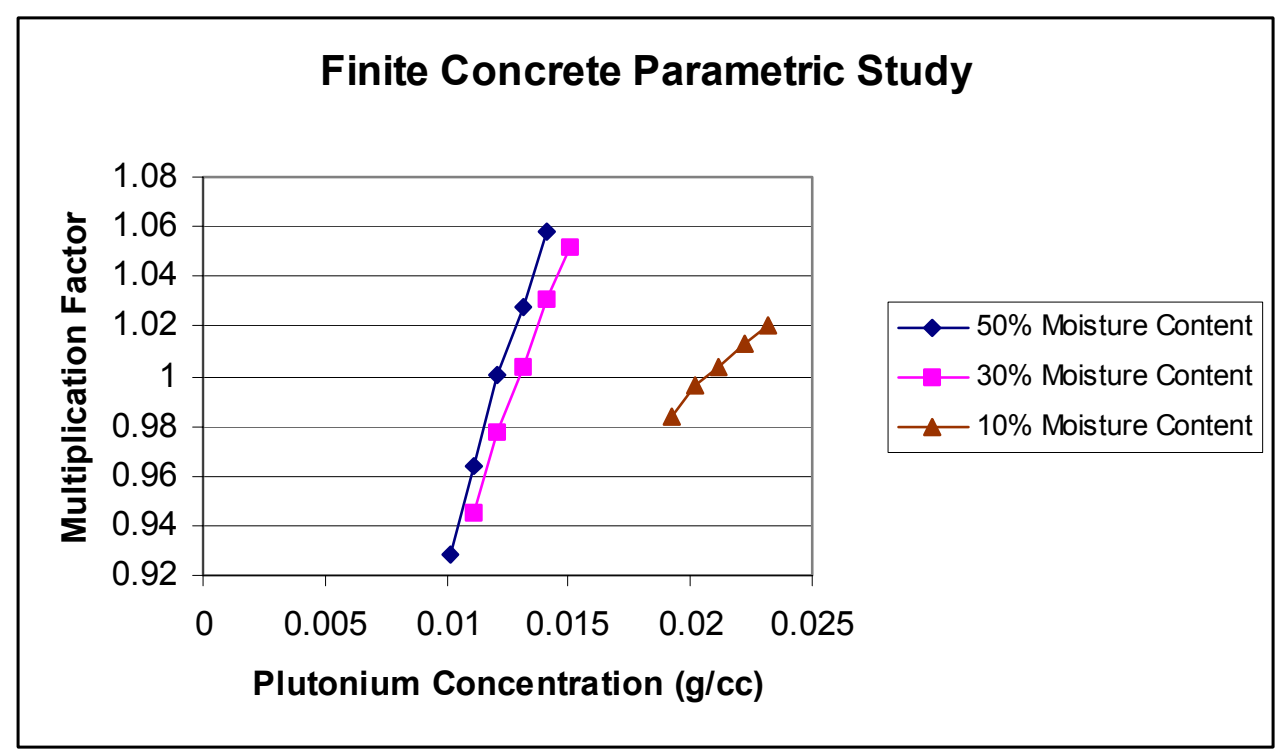

Figure 5C. Finite (104 Liter) Concrete Parametric Study. 
Table 12C. Infinite Paraffin Parametric Study.

\begin{tabular}{|c|c|}
\hline \multicolumn{2}{|c|}{ Paraffin Matrix } \\
\hline Pu Concentration in Concrete $(\mathrm{g} / \mathrm{cc})$ & $\mathrm{k}_{\text {eff }} \pm \sigma$ \\
\hline 0.0117 & $1.0971 \pm 0.0003$ \\
\hline 0.0107 & $1.0509 \pm 0.0003$ \\
\hline 0.0097 & $0.9998 \pm 0.0003$ \\
\hline 0.0087 & $0.9430 \pm 0.0003$ \\
\hline 0.0077 & $0.8811 \pm 0.0003$ \\
\hline
\end{tabular}

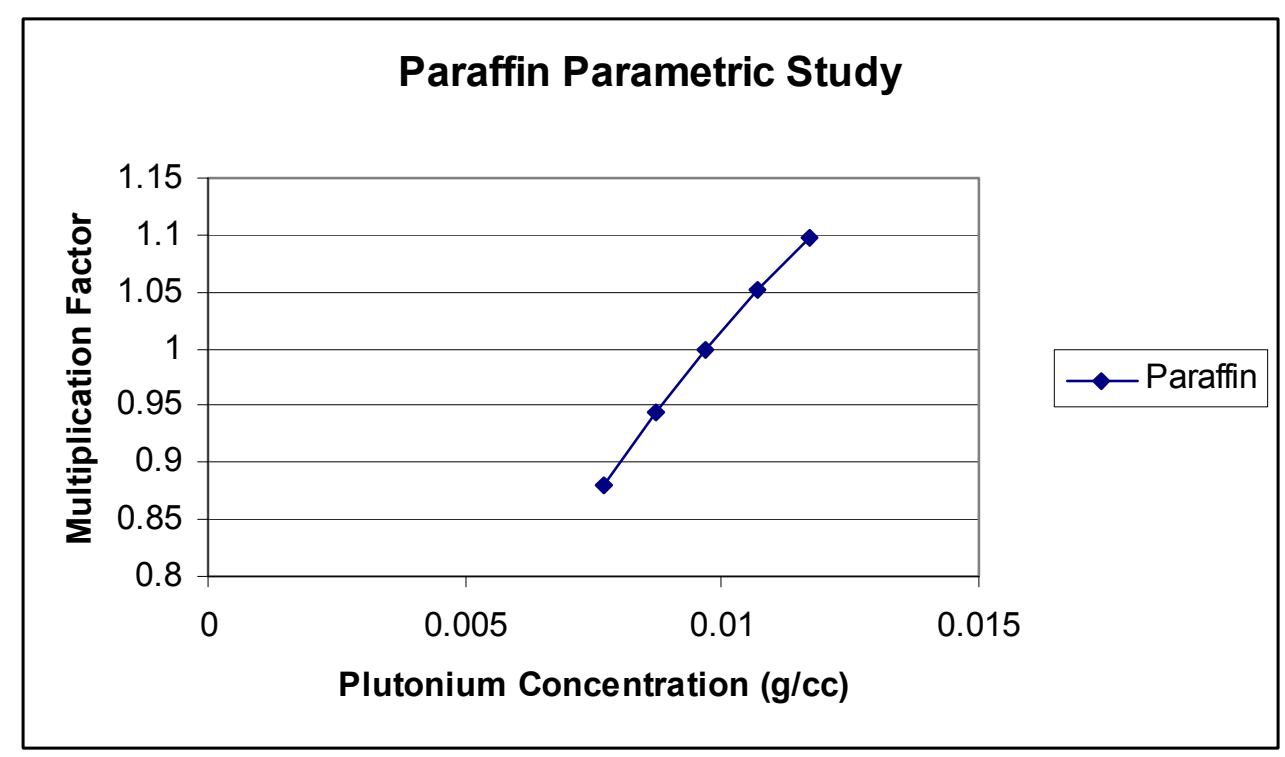

Figure 6C. Infinite Paraffin Parametric Study. 
Table 13C. Finite (208 Liter)Paraffin Parametric Study.

\begin{tabular}{|c|c|}
\hline \multicolumn{2}{|c|}{ Paraffin Matrix } \\
\hline Pu Concentration in Concrete $(\mathrm{g} / \mathrm{cc})$ & $\mathrm{k}_{\text {eff }} \pm \sigma$ \\
\hline 0.01325 & $1.00719 \pm 0.0007$ \\
\hline 0.01225 & $1.0355 \pm 0.0007$ \\
\hline 0.01125 & $0.9976 \pm 0.0006$ \\
\hline 0.01025 & $0.9525 \pm 0.0007$ \\
\hline 0.00925 & $0.9025 \pm 0.0007$ \\
\hline
\end{tabular}



Figure 7C. Finite (208 Liter)Paraffin Parametric Study. 
Table 14C. Finite (104 Liter) Paraffin Parametric Study.

\begin{tabular}{|c|c|}
\hline \multicolumn{2}{|c|}{ Paraffin Matrix } \\
\hline Pu Concentration in Concrete $(\mathrm{g} / \mathrm{cc})$ & $\mathrm{k}_{\text {eff }} \pm \sigma$ \\
\hline 0.0148 & $1.00648 \pm 0.0008$ \\
\hline 0.0138 & $1.0334 \pm 0.0008$ \\
\hline 0.0128 & $1.0005 \pm 0.0008$ \\
\hline 0.0118 & $0.9635 \pm 0.0008$ \\
\hline 0.0108 & $0.9213 \pm 0.0007$ \\
\hline
\end{tabular}

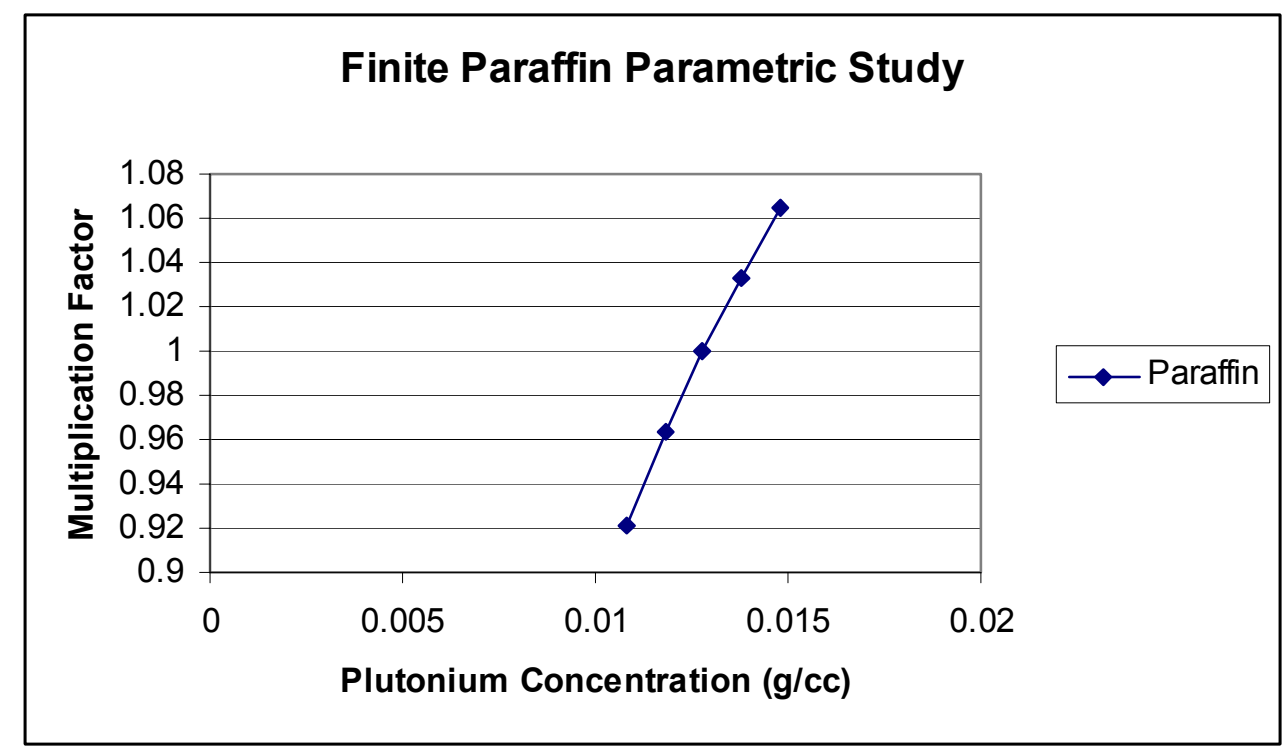

Figure 8C. Finite (104 Liter) Paraffin Parametric Study. 